\title{
Flavonoids and Colorectal Cancer Prevention
}

\author{
Yanyan $\mathrm{Li}^{1}{ }^{1}$, Tao Zhang ${ }^{2}$ and Grace $\mathrm{Y}$. Chen ${ }^{3, *}$ \\ 1 College of Science and Humanities, Husson University, Bangor, ME 04401, USA; liy@husson.edu \\ 2 Department of Basic Pharmaceutical Sciences, School of Pharmacy, Husson University, \\ Bangor, ME 04401, USA; zhangt@husson.edu \\ 3 Division of Hematology \& Oncology, Department of Internal Medicine, Rogel Cancer Center, \\ University of Michigan, Ann Abor, MI 48109, USA \\ * Correspondence: gchenry@umich.edu
}

Received: 26 September 2018; Accepted: 4 December 2018; Published: 10 December 2018

\begin{abstract}
Colorectal cancer (CRC) is the third most common cancer, but despite advances in treatment, it remains the second most common cause of cancer-related mortality. Prevention may, therefore, be a key strategy in reducing colorectal cancer deaths. Given reports of an inverse association between fruit and vegetable consumption with colorectal cancer risk, there has been significant interest in understanding the metabolism and bioactivity of flavonoids, which are highly abundant in fruits and vegetables and account for their pigmentation. In this review, we discuss host and microbiota-mediated metabolism of flavonoids and the potential mechanisms by which flavonoids can exert protective effects against colon tumorigenesis, including regulation of signaling pathways involved in apoptosis, cellular proliferation, and inflammation and modulation of the gut microbiome.
\end{abstract}

Keywords: flavonoids; chemoprevention; colorectal cancer; microbiota; inflammation

\section{Introduction}

Colorectal cancer is the third most common cancer worldwide [1]. Despite advances made in the treatment of colorectal cancer with improvement in survival rates with chemotherapy, colorectal cancer remains the second most common cause of cancer-related mortality and metastatic colorectal cancer remains an incurable disease [1]. An effective strategy for reducing colorectal cancer-related mortality is prevention, which includes screening, and indeed, increased screening with colonoscopies has been associated with reduced incidence of colon cancer [2]. Therefore, screening for colorectal cancer is recommended for people aged 50 and over [3]. However, while the rates of colon cancer in adults aged 50 and older have declined, there has been a disturbing increase in colorectal cancer incidence in adults younger than 50, who have not been typically not screened [4]. In fact, since 1994, there has been a $51 \%$ increase in colorectal cancer in patients aged 20-49, and this increase is not clearly linked to a genetic predisposition, suggesting that other factors, such as diet and/or physical activity may underlie the increase incidence in this population [5]. For these reasons, the American Cancer Society has lowered the recommended age to start colorectal cancer screening to 45 . Regardless, there is a clear need to define strategies to reduce colorectal cancer risk in addition to cancer screening.

As in most cancers, colorectal cancer is largely driven by the accumulation of genetic mutations in oncogenes and tumor suppressor genes that occur in a stepwise fashion [6,7], and therefore, increasing age and inherited mutations, such as in the adenomatous polyposis coli (Apc) tumor suppressor gene, are significant risk factors for the development of colorectal cancer [8]. This sequential accumulation of mutations is generally associated with the stepwise progression from normal intestinal epithelium to the development of a premalignant tumor, or adenoma, to a frank adenocarcinoma [6]. These mutations promote neoplastic transformation by disrupting cell biological processes that underlie 
the hallmarks of cancer, including evasion of apoptosis, increased cellular proliferation, and tumor invasion/metastases $[9,10]$. Another key promoter of colon carcinogenesis is chronic inflammation as it can lead to the production of growth factors inducing cellular proliferation, DNA-damaging oxygen radical species, extracellular matrix-modifying enzymes that can facilitate tissue invasion, and survival factors that lead to decreased apoptosis, resulting in a microenvironment conducive to tumorigenesis [10]. Indeed, patients with inflammatory bowel disease have a substantially higher risk of developing colorectal cancer than normal, healthy individuals [11]. Environmental factors can also contribute to colon carcinogenesis; specifically, physical activity, diet, and smoking, and alcohol intake can all influence colorectal cancer risk [12]. However, the mechanisms by which these activities affect colorectal cancer pathogenesis remains to be fully elucidated.

There is increasing evidence that the gut microbiome can also contribute to colorectal cancer risk, and changes in the gut microbiome are strongly linked to the diet, which in turn, has been associated with colorectal cancer risk $[13,14]$. The gut microbiota performs several vital functions for the human host, including dietary metabolism, colonization resistance against invasive pathogens, detoxification of potential carcinogens, and promotion of immune homeostasis $[15,16]$. More specifically, the gut microbiota can regulate regulatory $\mathrm{T}$ cell development and Th17 responses, both of which have been implicated in colon cancer progression and in development of inflammatory bowel disease, a major risk factor for colon cancer $[17,18]$. In addition, the gut microbiota can generate a significant number of metabolites that can have both local and systemic effects, notably secondary bile acids, which can promote colon cancer, and short-chain fatty acids (SCFAs), which have anti-inflammatory and epithelial regulatory activities that can protect against colorectal cancer development and can regulate epithelial repair and proliferation [19]. Thus, perturbations in the microbiome can affect host inflammatory and cell proliferative responses, which, in turn, can also impact colon tumorigenesis. Consistently, patients with colorectal cancer have an altered composition of the gut microbiome compared to healthy individuals, with reduced overall diversity and accumulations in certain bacterial populations including Fusobacterium nucleatum, entertoxigenic Bacteroides fragilis, and polyketide synthase-positive (pks+) Escherichia coli [20-26], and studies in mice have suggested that changes in the gut microbiome can directly contribute to colon tumorigenesis [27]. Thus, it is now presumed that pathologic alterations in the composition of the gut microbiome, also commonly referred to as dysbiosis, may lead to the accumulation of pro-inflammatory, pro-tumorigenic bacteria and/or the depletion of protective bacteria that have anti-inflammatory or tumor-suppressive activities [27]. How dysbiosis occurs remains unclear; however, both host genetics, inflammation, and carcinogenic stimuli, which can affect colon cancer susceptibility, can also cause changes in the gut microbiome [27,28]. Moreover, environmental and lifestyle factors that affect colorectal cancer risk, such as diet and smoking, can also potentially affect the microbiota composition $[29,30]$. Thus, nutritional intervention may be one strategy to modify the gut microbiome, inflammatory responses, and colorectal cancer risk.

Dietary interventions have generated significant interest as associations have been observed between consumption of certain foods and colorectal cancer risk with the strongest evidence suggesting a link between red meat consumption and increased risk, while foods containing wholegrains or dietary fiber are associated with decreased risk [12]. Diets high in fruits and vegetables have been inversely associated with many different types of cancers including colorectal cancer [31-33]. A class of compounds particularly abundant in these types of foods are flavonoids, and are rich in fruits, vegetables, red wine, and green tea, which have generally been associated with protective effects against cancer. In fact, a meta-analysis revealed that high intake of certain dietary flavonoids is associated with decreased risk of colon and rectal cancer [34]. However, the mechanisms by which flavonoids may suppress colon carcinogenesis remain to be fully elucidated, but have been related to their anti-inflammatory, antioxidant, and pro-apoptotic properties. In addition, certain members of the gut microbiota significantly contribute to the metabolism of flavonoids, and there is increasing evidence that flavonoids can also alter the composition of the gut microbiome, potentially giving the microbiota a central role in the bioactivity of flavonoids. In this review, the metabolism and bioavailability 
of flavonoids as well as potential mechanisms of action behind the protective effects against colon tumorigenesis using some of the more well-studied flavonoids as examples will be discussed.

\section{General Overview of Flavonoids}

Dietary polyphenols are natural compounds that have been used for years as nutraceuticals due to their various beneficial effects on human health. They are prevalent in fruits, vegetables, whole grains, and plant-derived beverages. Polyphenols are characterized by hydroxylated phenyl moieties with different number of phenolic rings and substituting groups. It is a large heterogeneous group of compounds which can be generally classified into flavonoids and non-flavonoids [35]. Flavonoids are the largest class of polyphenols and the most important in plant pigmentation. Aside from being pigments, flavonoids provide various biochemical functions in seed maturation, protection from different biotic and abiotic stresses, and heat acclimation and freezing tolerance, and act as detoxifying and defensive agents [36].

There are over 9000 flavonoids that have been described [37]. The core structure of flavonoids is a diphenylpropane skeleton (C6-C3-C6), which contains two phenyl rings and one heterocyclic ring (Figure 1) [38]. Their antioxidant capacity has largely been attributed to the presence of multiple 3- and 5-hydroxyl groups as well as $3^{\prime}$ - and 4'-catechol groups [39]. Based on their chemical structure, flavonoids can be classified further into six major subclasses: flavones, flavanones, flavanols, flavonols, isoflavones, and anthocyanins/anthocyanidins (Figure 1) [40,41]. Other flavonoids may include compounds such as biflavonoids (e.g., ginkgetin), flavanonols (e.g., taxifolin), prenylflavonoids (e.g., artocarpin), flavonolignans (e.g., silibinin), glycosidic ester flavonoids, and chalcones $[40,42]$. In plants, the majority of flavonoids exist in the form of glycosides [43].

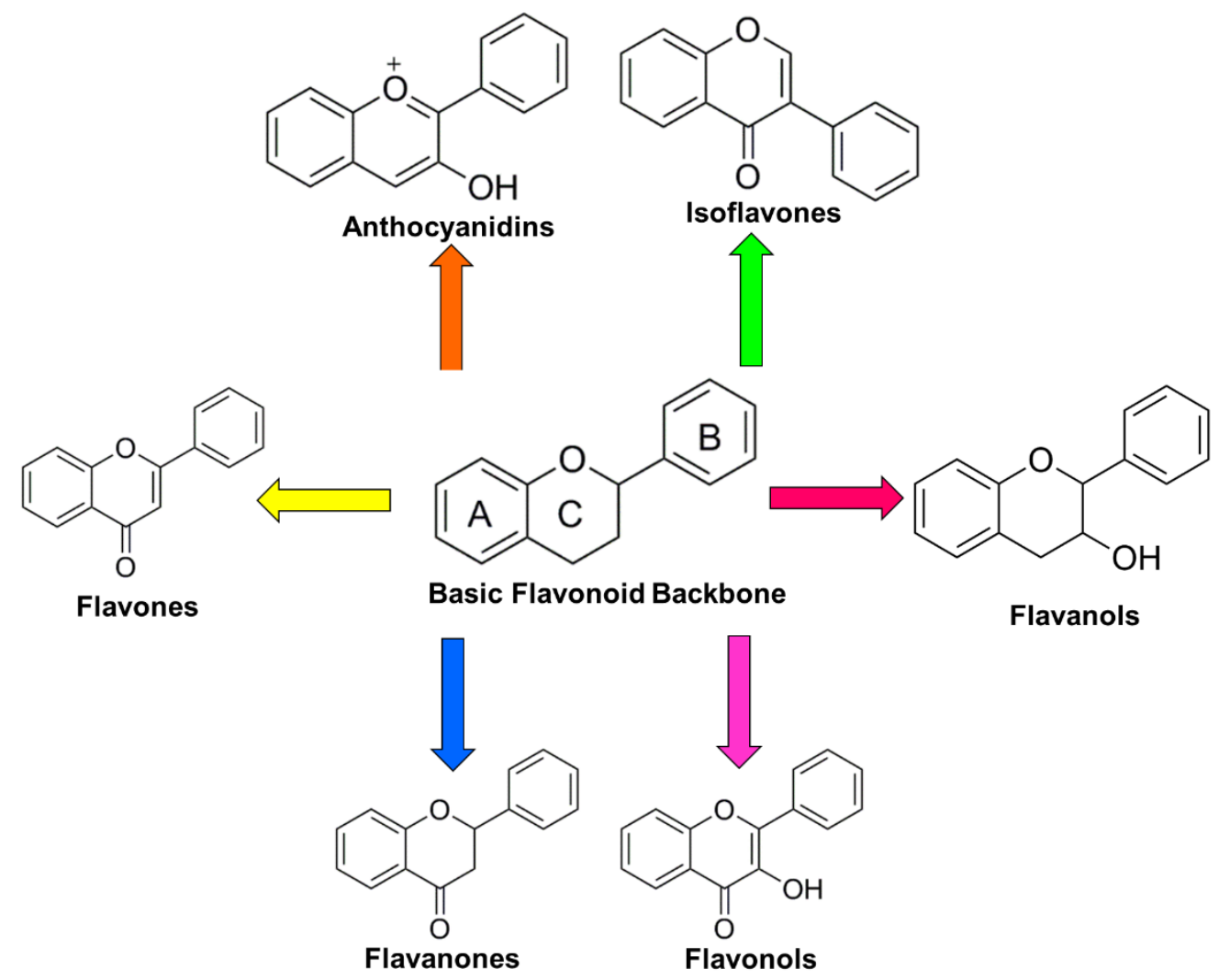

Figure 1. Basic structure of flavonoids and their subclasses. The core structure of flavonoids is a diphenylpropane skeleton (C6-C3-C6), which contains two phenyl rings and one heterocyclic ring. Based on their chemical structure, flavonoids can be further classified further into flavones, flavanones, flavanols, flavonols, isoflavones, and anthocyanins/anthocyanidins. 


\subsection{Flavones}

Flavones are a group of flavonoids characterized by a double bond between C-2 and C-3 in the flavonoid skeleton, and a non-saturated C-3 chain. Flavones are widely distributed among the higher plants and play a variety of important roles. They are the primary pigments or co-pigments in white and blue flowers, respectively [44]. The major flavones studied are apigenin and luteolin. Apigenin is one of the most prominent flavone aglycones. It is commonly found in vegetables, herbs and plant-derived beverages such as wine, beer, and chamomile $[45,46]$. Celery, artichokes, and parsley also contain high amounts of apigenin [47], while apigenin-7-glucoside (A7G) is present at high levels in red wine, artichokes and chamoumile [47]. Apigenin has shown prominent antibacterial, anti-inflammatory and antispasmodic effects [43]. Luteolin, like apigenin, occurs in many vegetables and fruits such as broccoli, celery, carrots, parsley, cabbages, peppers and apple skins [43]. As an antioxidant that scavenges reactive oxygen species (ROS) and as a pro-oxidant due to auto-oxidation, luteolin exhibits anti-cancer, anti-allergy, and anti-inflammatory effects [43].

\subsection{Flavanones}

The backbone structure of flavanone is 2,3-dihydro-2-phenylchromen-4-one [41]. Flavanones represent one of the largest subgroups of flavonoids. They are extensively disseminated in plants and especially rich in Citrus species. In the diet, orange juice is the foremost food that provides flavanones. Common flavanones are the aglycones such as naringenin, hesperetin, eriodictyol, isosakuranetin, and their respective glycosides [41]. Naringenin and its derivatives are typically found in grapefruit and sour oranges, while hesperetin and its derivatives are characteristic flavanones of sweet oranges, tangelos, lemons and lime [40]. Flavanones, of which naringenin has been studied the most extensively, are biologically active with antioxidant, anti-inflammatory, and anti-microbial activities $[43,48,49]$. The antioxidant activity of flavanones is highly dependent on a hydrophilic environment and the presence of a catechol group [43].

\subsection{Flavanols}

Flavanols constitute a very complex group of flavonoids with the backbone structure of 2-phenyl-3,4-dihydro-2H-chromen-3-ol, also known as flavan-3-ol [41]. Flavanols exist primarily in tea, wine, cocoa, apples and fruit juices or jams [41]. Catechins, which are known as the major building blocks of tannins, are the most important representatives of flavanols. Catechins are found abundantly in green and black tea. Different types of catechins include catechin, gallocatechin, catechin 3-gallate, gallocatechin 3-gallate, epicatechin, epigallocatechin, epicatechin 3-gallate, and epigallocatechin 3-gallate (EGCG) [43]. Proanthocyanidins are dimers, oligomers, and polymers of catechins, which are known as a type of condensed tannin [50].

\subsection{Flavonols}

Flavonols are a class of flavonoids with a 3-hydroxy-2-phenylchromen-4-one backbone [41]. This class of flavonoids are well-known for their antioxidant properties and other biological activities [43]. They are the most common flavonoids in fruit and vegetables, accumulating mainly in skin and leaves. Onions, leeks, kale, apples, berries, grapes, and grape products are all major food sources of flavonols [43]. The main representatives of flavonols are quercetin, kaempferol, myricetin, and isorhamnetin. 
Quercetin is found in onion, broccoli, apple, tea and red wine [46]. It is a water-soluble plant pigment with high antioxidant and anti-inflammatory activity [51-54]. Kaempferol is a flavonol antioxidant occurring in spinach, kale and broccoli [43]. It has been shown to regulate various signaling protein related to angiogenesis, apoptosis, metastasis and inflammation [55]. Myricetin is commonly found in berries, vegetables and in plant-derived teas and wines [56]. It occurs naturally in both free and glycosidically-bound forms and is poorly soluble in water [57]. Myricetin exhibits a wide range of biological activities including antioxidant, anti-cancer, anti-diabetic, and anti-inflammatory effects [56]. Isorhamnetin is the 3-methyl metabolite of quercetin but also occurs naturally in plants. It is extracted from herbal medicines such as Persicaria thunbergii H. and Hippophae rhamnoides L. [58]. Although it is less well-studied compared to quercetin, it has been demonstrated to have anti-cancer, anti-viral, and antioxidant effects [58-61].

\subsection{Isoflavones}

Isoflavones possess a 3-phenylchromen skeleton which is derived from the 2-phenylchromen system [43]. Soybeans and soy foods are the richest source of isoflavones [41], and red clover and kudzu also contain high amount of isoflavones [62]. Genistein and daidzein are the two major isoflavones, and have been studied extensively. Genistein, known as a phytoestrogen, can modulate steroid hormone receptors and multiple metabolic pathways, making it an important dietary ingredient that can prevent and treat common disorders [63]. Daidzein, another isoflavone present in soy, is an inactive analog of genistein. Daidzein is also a phytoestrogen that binds to estrogen receptors with both weak estrogenic and weak anti-estrogenic effects [64].

\subsection{Anthocyanins and Anthocyanidins}

Anthocyanins and anthocyanidins are a group of water-soluble pigments with significant antioxidant activity responsible for the blue, red, purple, and orange colors present in many fruits and vegetables, such as red-skinned grapes, apples, pears, radishes, and red/purple cabbage [65-67]. Anthocyanidins have the backbone structure of 2-phenylchromenylium [41], and are formed by the addition of glycose (mainly glucose), acyl, hydroxycinnamic acid or other moieties to the main structure of major anthocyanidins [68]. Anthocyanin, for example, is the glycoside form of the anthocyanidin, aglycone. Cyanidin, pelargonidin, delphinidin, malvidin, petunidin, and peonidin are the most commonly found anthocyanidins [65]. Cyanidin is a strong antioxidant present in most red colored berries such as bilberry, blackberry, blueberry, cherry, cranberry, elderberry, hawthorn, loganberry, and raspberry, and in other fruits such as apples, pears, peaches, and plums [65,69]. Pelargonidin is an anthocyanidin that produces an orange color [65] and is present in all berries, but primarily strawberries [70]. Delphinidin is an anthocyanidin that provides the blue-red colors of flowers, fruits, and red wine [65] while malvidin is responsible for the pigments in red grapes and blueberries. Malvidin possesses significant antioxidant capacity and exhibits anti-inflammatory effects [66,67]. Petunidin is an O-methylated anthocyanidin derived from delphinidin and provides blue-red pigments to flowers, fruits, and red wine. Peonidin is also an O-methylated anthocyanidin that gives purplish-red hues to flowers such as the peony as well as berries and vegetables.

\section{Host Metabolism of Flavonoids}

The bioavailability of flavonoids is generally poor, but can vary significantly among different classes as well as individual flavonoids [71]. Factors that affect bioavailability and absorption of a flavonoid include its molecular weight, the nature of glycosylation and metabolic conversion by host conjugating enzymes, and the composition of the gut microbiota [71]. Flavonoids occur in plants in several different forms, such as aglycones, esters, and glycosides [72] although the majority of plant flavonoids exist as glycosides [73-75]. The sugar moiety is coupled to the aglycone as O-glycosides via a hydroxy group and less frequently as C-glycosides [75]. After ingestion, flavonoid glycosides are absorbed in the small intestine where they are deglycosylated and further conjugated, while the 
rest pass into the colon where they are metabolized by the gut microbiota [73,76-79]. Two enzymes in the human small intestine have been identified to deglycosylate flavonoids [80-82]. Lactase-phlorizin hydrolase, a brush border enzyme, was reported to hydrolyze O-glucosides of quercetin, genistein, and daidzein in vitro [80]. Cytosolic beta-glucosidase in the enterocytes was reported to hydrolyze O-glucosides of quercetin, genistein, daidzein in cell-free extracts from human intestine [83].

Once deglycosylated, the produced flavonoid aglycons enter the intestinal epithelial cells, where phase II enzymes catalyze conjugation reactions [82]. Three types of phase II enzymes-uridine-5'-diphosphate-glucuronosyltransferases, sulfotransferases, and catechol-o-methyltransferases-have been identified that are capable of metabolizing flavonoids [82,84-86]. The conjugated flavonoids are subsequently absorbed into the circulation and transported to the liver where they undergo additional conjugation such as methylation and sulfation $[82,87]$. These flavonoid metabolites can then circulate systemically and exert their biological effects, or can return to the intestine via the bile [75,82,86-90]. Upon return into the intestine, flavonoid metabolites can be deconjugated by the gut microbiota and reabsorbed or act locally in the tissue $[75,82,91]$. This recycling of flavonoids through the enterohepatic circulation contributes to the improved plasma levels of flavonoids in humans [92].

\section{Microbial Metabolism of Flavonoids}

As many flavonoid glycosides are poorly absorbed in the small intestine, resulting in substantial quantities in the colon $[73,76-78]$, the gut microbiota can have a crucial role in the biotransformation of flavonoid glycosides. The diversity of the gut bacteria and enzymes they contain allow the formation of a variety of bioactive metabolites from flavonoids with varying anti-inflammatory, antioxidant, and anti-tumor activities [82,93,94]. For example, microbial metabolites of anthocyanins have been shown to affect the proliferation and viability of colon cancer cell lines in vitro although the concentrations used were quite high in the 10-100 $\mu \mathrm{M}$ range $[95,96]$. Thus, a better understanding of the bacterial populations and activities in flavonoid metabolism and bioavailability will be important to harness the beneficial effects of flavonoids for colorectal cancer prevention.

Flavonoids can be extensively metabolized into a range of products by the gut microbiota. Intestinal bacteria, including specific species such as Clostridium, Eubacterium, Lactococcus, and Parabacteroides, have the capacity to catalyze O-deglycosylation, C-deglycosylation, demethylation, dehydroxylation, ester cleavage, reduction of carbon-carbon double bonds, isomerization, ring fission, extension and truncation of the aliphatic carbon chain, and decarboxylation [75]. Heterogeneity in the composition of the gut microbiome may result in very different profiles of flavonoid metabolites between individuals as exemplified by a study of the metabolite profiles obtained from in vitro incubations of fecal-derived human microbiota from 10 different human subjects with extracts from black tea and a mixture of red wine and grape juice. There were significant inter-individual differences in the types and levels of metabolites produced [75,97], likely reflecting differences in bacterial populations and their respective activities between individuals.

Deglycosylation, the hydrolysis of glycosidic bonds, is usually the first step of microbial conversion of flavonoids to produce flavonoid aglycons. While some human glycosidases may hydrolyze O-glucosides, deglycosylation of C-glucosides and other C- and O-glycosides can only by performed by gut bacteria [75]. Specific human gut bacteria have been reported for O-deglycosylation of flavonoid glycosides, including a number of Bifidobacterium species [50,98,99], Lactobacillus species [50,98,99], Enterococcus species, and Bacteroides species [100-103]. The deglycosylation of flavonoid C-glycosides has not been well-investigated thus far. Some members of Lachnospiraceae, Enterococcaceae, and Streptococcaceae were reported to cleave the C-coupled flavone and isoflavone glucosides [103-107].

The flavonoid aglycons can be further metabolized into a variety of metabolites [82]. The phenolic rings of flavonoids often carry hydroxy- and methoxy- groups [75], and either dehydroxylation or demethylation can occur via the enzymatic activity of Eubacterium, Blautia, Eggerthella, Adlercreutzia, 
and Escherichia [108-114]. Moreover, some human gut bacteria, for example, Eubacterium ramulus and Flavonifractor plautii, can also degrade aglycones of the different flavonoid subtypes into small molecules with bioactivity $[75,79,100,115-121]$. These metabolites include various ring-fission products. For example, the B-ring of the flavanonols may be converted into hydroxyphenylacetic acids and the A-ring into short-chain fatty acids (SCFAs) [75]. The C-ring of the flavanones may be transformed into dihydrochalcones [75]. Degradation of isoflavone aglycones may result in equol or O-desmethylangolensins, which may be further cleaved into small phenolic products $[75,82]$. These metabolites are generally bioavailable from the colon, and may have potent activities locally and systematically. Whether the relative abundances of specific bacterial populations in the gut determine flavonoid metabolite profiles and the relative potency of these metabolites in mediating colorectal cancer risk remains to be determined. Intriguingly, quercetin, for example, can be metabolized and degraded into the SCFAs acetate and butyrate, which have been associated with cytoprotective effects in the intestinal epithelium and protection against colon tumorigenesis $[79,122,123]$. Thus, it is possible that the efficacy of a flavonoid is largely dependent on the ability of an individual's microbiota to generate specific bioactive metabolites with anti-tumor activity.

\section{Anti-Colorectal Cancer Effects of Major Flavonoids}

\subsection{Anthocyanidins}

Anthocyanins and their metabolites, anthocyanidins, provide a variety of health benefits attributed to their antioxidant, anti-inflammation, and anti-cancer activities [39,41,124-126]. Anthocyanins have been reported to reduce both colorectal cancer and inflammatory bowel disease, a major risk factor for the development of colorectal cancer. Its protective activities have been largely attributed to its ability to negatively regulate inflammatory signaling pathways including nuclear factor kappa light chain enhancer of activated B cells (NF-kB), mitogen-activated protein kinase (MAPK), c-Jun N-terminal kinase (JNK) and signal transducer and activator of transcription (STAT). It is also capable of inhibiting cell proliferative pathways such as the Wnt signaling pathway, which is upregulated in the majority of sporadic colorectal cancers $[79,127]$. The anthocyanidins delphinidin and cyanidin, for example, have been shown to have direct cytotoxicity against metastatic colon cancer cell lines in vitro [128], leading to apoptosis. This was not necessarily related to its antioxidant effects as both, in fact, acted as pro-oxidants with ROS accumulation in tumor cells that may increase oxidative stress and induce an apoptotic response [129]. Interestingly, this effect was not observed for all anthoycanidins, as malvidin (the $3^{\prime}, 5^{\prime}$-methoxy derivative of delhinidin) and pelargonidin did not have any anti-tumor activity and moreover, the protective effect of delphinidin and cyanidin was not observed with all colorectal cancer cell lines. Delphinidin, in particular, upregulated the expression of p53, which can induce cell cycle arrest and apoptosis [130]. Consistently, there was increased expression of the pro-apoptotic factor B-cell lymphoma 2-associated $X$ protein (Bax) and concomitant decrease in expression of the anti-apoptotic factor (B-cell lymphoma 2) Bcl-2 associated with inhibition of NFkB, a regulator of Bcl-2 and Bax expression [130]. Bcl-2, the anti-inflammatory effect of anthocyanin was confirmed in a mouse model of chemically-induced colitis by dextran sulfate sodium (DSS), a chemical which directly injures the intestinal epithelium causing a bacterial-driven inflammatory response, using either 1 or $10 \%$ anthocyanin extract derived from bilberries [131]. In addition, treatment of $\mathrm{Balb} / \mathrm{c}$ mice with a $10 \%$, but not $1 \%$, anthocyanin-rich extract reduced the number of tumors that developed in a mouse model of inflammation-associated colon tumorigenesis in which mice are first injected with an experimental carcinogen, azoxymethane (AOM), followed by multiple rounds of water containing dextran sulfate sodium (DSS) to induce chronic inflammation that mimics inflammatory bowel disease in humans (AOM/DSS model), although there are features of this model that also recapitulate human sporadic colon cancer [131,132]. In another study using the AOM/DSS model, C57BL/ 6 mice fed an extract containing black raspberry anthocyanins (purity $>90 \%$ ), consisting mostly of cyanidin-O-glucoside, cyanidin-O-xylosylutinoside, and cyanidin-O-rutinoside, reduced 
both inflammation and tumor numbers compared to that of control mice. Interestingly, the addition of anthocyanin extracts reversed potentially pathologic changes in the gut microbiome as determined by terminal restriction fragment length polymorphism (T-RFLP) analysis after AOM/DSS treatment, namely a reduction in the pro-inflammatory Enteroccoccus species while increasing Eubacterium rectale, Faecalibacterium prausnitzii, and Lacobacillus that have typically been associated with anti-inflammatory and anti-proliferative capabilities [133]. In addition, changes were observed in the expression of the DNA methyltransferases DNMT31 and DNMT3B, that can lead to promoter demethylation of genes involved in tumor suppression, for example, secreted frizzled-related protein 2 (SFRP2), an antagonist of the Wnt pathway, which is disrupted in the majority of colorectal cancers $[127,133]$. Consistently, an effect on demethylators was also observed in another study after addition of black raspberry-derived extract to various colon cancer cell lines [134]. Although the dose of extract used was relatively high, another study using a bilberry extract resulting in a dietary anthocyanin content of $0.3 \%$, an amount more achievable in humans, resulted in reduced adenoma formation in $\mathrm{Apc}^{\mathrm{Min}}$ mice, which harbor a mutation in the Apc tumor suppressor gene that commonly occurs in human sporadic colon cancers $[135,136]$.

The most compelling evidence of a protective anti-inflammatory and anti-proliferative effect for anthocyanidin came from human studies in which the ingestion of an anthocyanidin-rich bilberry extract ameliorated colitis and was associated with reduced NFKB activation and production of pro-inflammatory mediators in colon biopsies from inflammatory bowel disease patients $[137,138]$ and reduced cellular proliferation in tumor samples from colorectal cancer patients [139]. Consumption of black raspberry powder was also associated with changes in methylation status of various tumor suppressor gene promoters, increased apoptosis, and decreased surrogate markers of cellular proliferation in biopsies of colorectal cancers and normal adjacent tissue [140]. These studies, however, were small and also involved extracts and freeze-dried black raspberry powder, and therefore can contain numerous other bioactive compounds with anti-tumor activity. Therefore, additional studies in a larger population with purified compounds will be needed to determine more precisely the anti-tumor effects of particular anthocyanidins.

\subsection{Apigenin}

Apigenin, one of the flavones, has multiple activities that promote its anti-colorectal cancer effect. Although there have been no clinical trials conducted to date evaluating the effects of apigenin supplementation on colorectal cancer prevention, in one prospective study, 87 high-risk patients who either had a history of resected colorectal cancer or a polypectomy for an adenoma were given a flavonoid mixture consisting of $10 \mathrm{mg}$ apigenin and $10 \mathrm{mg}$ epigallocatechin-gallate or nothing over a period of 2-5 years with $67 \%$ of treated patients taking the flavonoid supplement more than 1 year with no adverse side effects. Although there was no statistically significant difference in colon cancer or adenoma recurrence rates between the treated and control groups, there was a trend for more favorable outcomes in the treatment group with cancer recurrence in $20 \%$ of controls and none in the treated group. However, the combined recurrence for neoplasia (cancer and adenoma) was significantly lower in the treatment group compared to that of the control group [141]. In addition, in the Polyp Prevention Trial, a dietary intervention trial in which 2079 subjects were randomized to either a control arm or to a low-fat, high fruit and vegetable diet, high apigenin intake was inversely associated with advanced adenoma recurrence [142]. 
Most data supporting the protective effect of apigenin against the development of colorectal cancer are largely from preclinical studies using colorectal cancer cell lines and animal models. Apigenin can induce G2/M cell cycle arrest of multiple colon cancer cell lines including SW480, HCT116, HT-29, and Caco-2 to varying degrees, which was associated with decreased expression of cyclin B1 proteins and the cyclin dependent kinase p34(cdc2) [143-146]. The induction of apoptosis may be related to its ability to its pro-oxidative effect, leading to increased ROS production and oxidative stress [147]. Like anthocyanidins, apigenin can also promote apoptosis by inducing the expression of p53 and altering the Bax/Bcl-2 ratios [148,149].

Apigenin can also affect multiple signaling pathways involved in cellular proliferation. For example, apigenin can inhibit Wnt signaling in colorectal cancer cells in vitro, possibly through an autophagy-dependent pathway with subsequent downregulation of Wnt target genes such as cyclin D1 and c-myc that are involved in colon epithelial proliferation [150-152]. Other inflammatory and cell proliferative pathways such as MAPK and extracellular signal-regulated kinase (ERK) can be affected by apigenin in colon cancer cells although how these different pathways interact to affect colon tumorigenesis remains to be fully elucidated [153].

In vivo studies using mouse models of colon cancer have not yielded consistent robust anti-tumor effects. In CF-1 mice injected with either a single dose of azoxymethane for 4 or 6 weeks to induce aberrant crypt foci, a lesion believed to precede the development of carcinoma, only $0.025 \%$, but not $0.1 \%$ apigenin-fed mice exhibited a reduction in tumor incidence [154]. In the ApcMin mouse model, there was also no significant difference, although the relevance of this model for human colon cancer given the predominance of tumors in the small intestine has been disputed [136,154,155]. However, in rats injected with $\mathrm{AOM}$, a significant decrease in the number of aberrant crypt foci was observed in the group fed $0.1 \%$ apigenin diet group for 10 weeks prior to AOM injection, associated with reduced proliferating cells and increased apoptosis [156]. Whether the discrepancy in results from results reflect differences in the animal model used, the diet preparation, the purity of apigenin, and length of exposure remains to be determined.

It is possible, however, that maximal effects of apigenin may be more evident in the context of inflammation given its ability to inhibit pro-inflammatory pathways $[157,158]$. Consistently, in both models of inflammatory bowel disease and colitis-associated colon cancer, mice exhibited reduced NFKB activation and STAT3 activation, which has been linked to increased epithelial proliferation [158], and decreased expression of pro-inflammatory cytokines and chemokines [159]. Additional insight into the ability of apigenin to inhibit inflammation and inflammation-induced colon tumors was provided by another study which implicated a role for the gut microbiota and innate immune signaling. In particular, when C57BL/6 mice treated with apigenin were cohoused with a second cohort of wildtype control mice not exposed to apigenin to allow microbiome transfer between mice, the control mice were similarly protected from DSS-induced colitis as the apigenin-treated mice, suggesting that the protective, anti-inflammatory effect of apigenin was mediated in part by the gut microbiota [160]. Indeed, it was demonstrated that ingestion of apigenin was associated with changes in the composition of the gut microbiome, namely, an expansion of Rikenellacae, Bacteroidales, and Bacteroides, and depletion of Clostridium and Lachnospiraceae, a phenotype similarly observed in control mice after cohousing. Interestingly, these changes were not observed in apigenin-treated mice deficient in the innate immune receptor NLRP6, and consistently, apigenin-treated NLRP6-deficient mice were more susceptible to DSS-induced colitis compared to apigenin-treated wildtype mice, strongly suggesting a role for NLRP6 in mediating the protective effect of apigenin as well. In fact, apigenin was capable of inducing NLRP6 expression within the intestinal epithelium. NLRP6 is a member of the Nod-like receptor (NLR) family of innate immune receptors that are capable of sensing microbes and tissue damage and has been shown to be important for regulating the composition of the gut microbiota and for protecting against the development of colitis as well as inflammation-associated tumorigenesis [28,161-164]. The mechanism by which NLRP6 regulates microbiome composition remains unclear although it appears to be dependent on IL-18, which can upregulate expression of antimicrobial proteins $[28,161]$. 
Consistently, mice deficient in the antimicrobial peptide Reg3III that is regulated by NLRP6 are also not protected from colitis after treatment with apigenin [160]. An effect of apigenin on gut bacteria was also verified in vitro in which apigenin was added to anaerobic cultures of human fecal microbiota as well as single bacterial isolates, which affected the growth and gene expression of certain bacteria [165]. How these effects ultimately translate into protection against colon tumorigenesis remains to be determined; clearly more studies are needed to clarify the relative importance of the different apigenin-protection mechanisms in colon cancer suppression.

\subsection{Quercetin}

As with other classes of flavonoids, the flavonol quercetin has been demonstrated to have anti-tumor activity against colon cancer cells both in vitro and in vivo. Mechanisms for its cytotoxic activity against colon cancer cells include induction of apoptosis via activation of p53 and inhibition of NFKB [166,167], cell cycle arrest as a result of downregulation of cell cycle genes [168-170], and suppression of inflammation via downregulation of Cox2, which is commonly upregulated in colon cancer [171]. Quercetin is also capable of regulating multiple signaling pathways involved in inflammation and cellular proliferation such as the Wnt pathway [169,172], NFKB, PI3K, MAPK, and protein kinase B (Akt) $[166,173]$. Another potential mechanism by which quercetin can affect cellular proliferation of colon cancer cells is by upregulating expression of the G-protein coupled cannabinoid receptor, CB1-R, which in turn can bind to quercetin, resulting in inhibition of cell growth and migration via Wnt, PI3K, Akt, and STAT3 pathways [174]. This effect was abrogated in the presence of a CB1-R antagonist.

Consistent with its in vitro effects, there are multiple studies that demonstrate the efficacy of quercetin in reducing tumor numbers in both mice and rats treated with azoxymethane [175-178]. Quercetin has also been shown to stimulate the growth of specific bacteria when exposed to human fecal microbiota in vitro with increases in the relative abundance of bacteria belonging to the Actinobacteria, Firmicutes, and Bacteroides phyla [179]. In vivo, alterations in the gut microbiome associated with quercetin treatment have also been reported [180]. Specifically, in an adoptive T-cell transfer model of colitis in which $\mathrm{T}$ cells depleted of regulatory $\mathrm{T}$ cells were transferred into T-cell deficient $\mathrm{Rag}^{-{ }^{-}-}$as well as the DSS chemically-induced colitis model, administration of quercetin resulted in amelioration of colitis that was associated with macrophages expressing an anti-inflammatory gene signature [180]. In addition, quercetin treatment resulted in reduced abundance of Proteobacteria, which commonly blooms in colitis and during inflammation and in patients with inflammatory bowel disease (IBD) [181,182], as well as an increase in Bacteroides and segmented filamentous bacteria (SFB), which promotes pro-inflammatory Th17 responses [183]. Decreases in Actinobacteria were also noted, which is inconsistent with what was observed in vitro and may reflect greater microbial complexity in vivo $[179,180]$. However, these changes were observed on day 45 after adoptive transfer when colitis is already present, and therefore, it is possible that the observed alterations in the composition of the gut microbiota reflect the severity of inflammation rather than a direct effect from quercetin. Whether quercetin induces changes in the gut microbiota that are beneficial prior to the onset of inflammation remains to be determined.

To date, there are no studies that demonstrate positive effects of quercetin supplementation on colorectal cancer risk in humans. Its potential chemopreventive effects have largely been extrapolated from case-control studies correlating quercetin content based on food frequency questionnaires, that may not have accurately quantified all food sources of flavonoids, with colorectal cancer incidence. For example, in an Italian study, consumption of flavonols of which quercetin, myricetin, and kaempferol were the major constituents evaluated significantly decreased the risk of colorectal cancer [184]. In the Polyp Prevention Trial, although high intake of flavonols, including quercetin, was associated with a significant decreased risk in advanced adenoma recurrence, there was no association between quercetin alone and adenoma recurrence [142]. In addition, in the Women's Healthy Study and Health Professionals Followup Study, two prospective cohort studies consisting of 
71,976 and 35,425 evaluable women and men, respectively, there was no association between quercetin intake or even total flavonoid intake with colorectal cancer risk, although the authors of the study noted that the questionnaire used was not designed to accurately assess flavonoid intake and that dietary changes may not have been captured with a one-time questionnaire [185]. It is also possible that the dietary source of quercetin may be important as a case-control study demonstrated that increased quercetin intake was associated with a small reduction in risk of proximal colon, but not distal colon cancers, and this effect was observed only with high fruit, but low tea intake [186]. This suggests that the food source of quercetin may affect bioavailability. Indeed, it was demonstrated that higher plasma concentrations of quercetin was achieved from the consumption of onion powder as compared to apple peel powder, and similarly, higher bioavailability was achieved with ingestion of quercetin-enriched cereal bars compared to powder filled capsules [71,187,188]. Alternatively, the presence of other bioactives in foods may interact with quercetin and further modulate tumor risk. Thus, additional studies will be needed to understand the relationship between quercetin intake and colon cancer.

\subsection{Epigallocatechin-3-Gallate}

The beneficial effect of tea has largely been attributed to its epigallocatechin-3-gallate (EGCG), rather than epicatechin and epigallocatechin, content [41]. EGCG is the main flavonoid in green tea ( $10-15 \%$ in an extract from green tea leaf), and there have been several studies demonstrating a protective effect of green tea against the development of recurrent adenomas and colon cancer [189-192]. Although these effects are likely not entirely due to the activity of EGCG alone, in vitro studies suggest a variety of anti-tumor mechanisms similar to those reported for other flavonoid subtypes. EGCG can inhibit not only the growth of colon cancer cells, but also their spheroid forming ability, an indicator of stem cell function $[193,194]$. This may, in part, be due to its ability to downregulate Wnt signaling [195], since activation of the Wnt pathway by lithium chloride can reverse the effects of EGCG and its ability to induce apoptosis [194]. EGCG can also inhibit Akt and NFkB pathways leading to reduced cyclooxygenase-2 (Cox-2) expression [196]. Moreover, although its hydroxyl groups can act as potent scavengers of reactive oxygen species, EGCG, as well as other flavonoids, can also undergo auto-oxidation to generate oxidizing radicals which, in turn, can act as a stress signal to activate pathways such as JNK to initiate cyctochrome c release and apoptosis [197-199]. Although it has been debated whether auto-oxidation is a phenomenon that occurs only in vitro as oxygen levels within tissues tend to be lower than that of culture media, at least one study demonstrated increased oxidative stress in lung xenograft tumors in the presence of EGCG [200,201]. Nonetheless, the relative antioxidant and pro-oxidant properties of EGCG and what actually occurs in vivo to affect tumor susceptibility will require further study. EGCG can also affect DNA methylation by regulating the expression of DNA methyltransferases [202]. For example, EGCG administration to HCT116 colon cancer cells can lead to the downregulation of DNMT3a gene expression as well as increased degradation of the protein [203]. Consistently, EGCG treatment resulted in reduced methylation of colon cancer-related genes, such as $\operatorname{RXR} \alpha, \mathrm{Apc}$, and hMLH1 [204]. However, it remains unclear whether this is a predominant mechanism by which EGCG contributes to inhibition of colorectal carcinogenesis as the data is correlative only. 
Animal studies indicate that EGCG is capable of reducing colon tumorigenesis. In rats, EGCG reduced the number of tumors that developed with AOM treatment [205,206]. The decreased tumorigenesis was associated with reduced Wnt signaling and Cox2 expression [205]. In mice, EGCG administration resulted in a significant decrease in tumors after treatment with AOM/DSS that was associated with changes in the microbiota at 8 weeks, namely Bifidobacterium and Lactobacillus (that have potential anti-inflammatory effects) were increased. As inflammation itself can alter the composition of the gut microbiota, whether the observed changes in abundance in certain bacterial populations with EGCG directly contribute to tumor suppression or merely reflect changes in the severity of inflammation remain to be determined and can be better addressed using gnotobiotic mice. In humans, the consumption of green tea resulted in changes in the gut microbiome, including increases in short-chain fatty acid-producing bacteria such as Lachnospiraceae, Bifidobacteriaceae, and Ruminococcaceae, and decreases in potentially proinflammatory bacteria, such as Prevotella, which was reported to be increased in patients with colorectal cancer $[20,162,207,208]$. However, whether these changes are due to EGCG and responsible for its protective effects is not known.

\section{Conclusions}

Despite the mounting evidence that high consumption of fruits and vegetables are inversely associated with colorectal cancer risk, observational studies have not provided consistent results regarding the relationship between flavonoid intake and colorectal cancer risk. For example, a recent large European cohort study consisting of 477,312 adults showed no association between intake of individual flavonoid subclasses as estimated by dietary questionnaire with colorectal cancer risk after an average of 11 years of follow-up [209] (Table 1). On the other hand, a meta-analyses of 18 cases involving 559,486 participants with 6-26 years of follow-up showed a potential colon cancer risk-reducing effect of specific flavonoid subclasses [210]. Differences in outcomes may, in part, reflect the limitations in the dietary questionnaires used and available food databases to accurately estimate flavonoid content as well as the significant inter-individual genetic and microbiome differences that exist among human subjects. However, multiple in vitro and in vivo preclinical studies, as reviewed above (Table 2), have demonstrated anti-tumor effects of specific flavonoids. The discrepancy between observational and preclinical studies may be due to the dosing of flavonoids in rodents and in cell culture that may not be achievable through the diet in human studies and more importantly, highlights the difficulty in translating preclinical data to clinical trials. Regardless, results from a limited number of small intervention trials, such as the Polyp Prevention Trial, hold promise for flavonoids as colon cancer chemoprevention agents [142].

Thus, much remains to be learned about the specific effects of the different flavonoids and their respective metabolites on colon cancer progression, which may allow the design of a nutritional intervention that optimizes the concentrations of the most bioactive compounds. Complicating this problem further is the ability of flavonoids and other dietary components to affect the growth of specific bacterial populations, which, in turn, can impact the metabolism and bioavailability of flavonoids as well as influence the development of colorectal cancer. 
Table 1. Select human studies of flavonoids and colorectal cancer.

\begin{tabular}{|c|c|c|c|c|c|c|c|}
\hline Type of Food/Flavonoid & Subjects & Type of Study & No. of Subjects & Dose & Length of Study & Outcome & Reference \\
\hline $\begin{array}{l}\text { Anthocyanidin-rich } \\
\text { bilberry extract }\end{array}$ & Ulcerative colitis & Intervention & 13 & $10 \mathrm{mg} / \mathrm{mL}$ & $\begin{array}{l}6 \text { weeks; } 9 \text { weeks } \\
\text { follow-up }\end{array}$ & $\begin{array}{l}\text { Reduced NF-kB activation and } \\
\text { production of pro-inflammatory } \\
\text { mediators in colon biopsies }\end{array}$ & {$[137,138]$} \\
\hline $\begin{array}{l}\text { Anthocyanidin-rich } \\
\text { bilberry extract }\end{array}$ & Colorectal cancer & Intervention & 25 & $0.5-2.0 \mathrm{~g}$ & 7 days & $\begin{array}{l}\text { Reduced cellular proliferation } \\
\text { in tumors }\end{array}$ & [139] \\
\hline Black raspberry powder & Colorectal cancer & Intervention & 20 & $60 \mathrm{~g}$ & $1-9$ weeks & $\begin{array}{l}\text { Decreased methylation of various } \\
\text { tumor suppressor gene promoters, } \\
\text { increased apoptosis, and decreased } \\
\text { surrogate markers of cellular } \\
\text { proliferation in colorectal cancer and } \\
\text { normal adjacent tissue biopsies }\end{array}$ & [140] \\
\hline $\begin{array}{l}\text { Apigenin/(-)-epigallocatechin } \\
\text { gallate (EGCG) }\end{array}$ & $\begin{array}{l}\text { Polypectomy and } \\
\text { resected CRC patients }\end{array}$ & 2-arm intervention & 87 & $20 \mathrm{mg}$ apigenin, $20 \mathrm{mg}$ EGCG & 304 years & $\begin{array}{l}\text { Decreased recurrence rate of } \\
\text { neoplasia (adenoma or CRC) }\end{array}$ & [141] \\
\hline Quercetin & $\begin{array}{l}\text { Healthy versus } C R C \\
\text { patients }\end{array}$ & Case-control & 2664 & $\begin{array}{c}\text { Quercetin intake } \\
\text { estimated based on food } \\
\text { frequency questionnaires }\end{array}$ & & $\begin{array}{l}\text { Inverse association between } \\
\text { proximal, but not distal colon cancer } \\
\text { risk and quercetin intake }\end{array}$ & [186] \\
\hline $\begin{array}{l}\text { Flavonoids/quercetin, } \\
\text { myricetin, kaempferol }\end{array}$ & Healthy & Observational & $\begin{array}{l}\text { 71,976 women, } \\
\text { 35,425 men }\end{array}$ & $\begin{array}{c}\text { Total flavonoid and } \\
\text { individual flavonol intake } \\
\text { based on food frequency } \\
\text { questionnaire }\end{array}$ & & $\begin{array}{l}\text { No association between flavonoid } \\
\text { intake CRC risk }\end{array}$ & [185] \\
\hline Flavonols & $\begin{array}{l}\text { History of } \\
\text { adenomatous polyp }\end{array}$ & $\begin{array}{c}\text { Randomized } \\
\text { intervention trial }\end{array}$ & 1905 & $\begin{array}{c}\text { Low-fat, high fiber, } \\
\text { high vegetable and fruit } \\
\text { intake vs. no intervention } \\
\text { control questionnaire }\end{array}$ & 4 years & $\begin{array}{l}\text { High intake of flavonols was } \\
\text { associated with significantly } \\
\text { decreased risk of advanced } \\
\text { adenoma recurrence }\end{array}$ & [142] \\
\hline EGCG & Polypectomy patients & $\begin{array}{c}\text { Randomized } \\
\text { intervention trial }\end{array}$ & 136 & $\begin{array}{c}1.5 \mathrm{~g} \text { green tea extract tablets } \\
\text { (52.5 mg EGCG) }\end{array}$ & 1 years & $\begin{array}{l}\text { Reduced incidence of } \\
\text { adenoma recurrence }\end{array}$ & [192] \\
\hline Green tea & Healthy & Intervention & & $400 \mathrm{~mL}$ green tea liquid & 2 weeks & $\begin{array}{l}\text { Alterations in the gut microbiome, } \\
\text { including increased short-chain fatty } \\
\text { acid-producing bacteria and } \\
\text { decreased pro-inflammatory bacteria }\end{array}$ & [207] \\
\hline Flavonoid & Healthy & Observational & 477,312 & $\begin{array}{c}\text { Flavonoid intake } \\
\text { based on food } \\
\text { frequency questionnaires }\end{array}$ & $\begin{array}{l}\text { Mean follow-up } \\
11 \text { years }\end{array}$ & $\begin{array}{c}\text { No association between total } \\
\text { flavonoid intake and risk of CRC or } \\
\text { any CRC subtype }\end{array}$ & [209] \\
\hline
\end{tabular}


Table 2. Preclinical studies of effect of flavonoids on colon tumorigenesis.

\begin{tabular}{|c|c|c|c|c|c|}
\hline Type of Flavonoid & Class & Dose & Model & Results & Reference \\
\hline Black raspberry anthocyanin extract & Anthocyanidin & $\begin{array}{l}5 \% \text { or } 10 \% \text { extract, or } 3.5 \mu \mathrm{mol} / \mathrm{g} \\
\text { and } 7.0 \mu \mathrm{mol} / \mathrm{g} \text { anthocyanin } \\
\text { concentration in diet }\end{array}$ & $\begin{array}{l}\text { Azoxymethane (AOM)/dextran sulfate } \\
\text { sodium (DSS) model of C57BL/ } 6 \text { mice }\end{array}$ & $\begin{array}{l}\text { Reduction in colon carcinogenesis; } \\
\text { reduction of pathogenic bacteria }\end{array}$ & [133] \\
\hline $\begin{array}{l}\text { Black raspberry-derived } \\
\text { anthocyanins }\end{array}$ & Anthocyanidin & $0.5,5$ and $25 \mu \mathrm{g} / \mathrm{mL}$ & $\begin{array}{l}\text { Human colorectal carcinoma cell line } \\
\text { HCT116, Caco2, and SW480 cells }\end{array}$ & $\begin{array}{l}\text { Suppressed activity and protein expression of } \\
\text { DNMT1 and DNMT3B }\end{array}$ & [134] \\
\hline Cyanidin and delphinidin & Anthocyanidin & $25-100 \mu \mathrm{M}$ & $\begin{array}{l}\text { Human colorectal carcinoma cell line Caco-2, } \\
\text { LoVo/ADR cells }\end{array}$ & Induced cell death & [128] \\
\hline Delphinidin & Anthocyanidin & $30-240 \mu \mathrm{M}$ & Human colon cancer HCT116 cells & Induced cell death; inhibition of NFKB & [130] \\
\hline $\begin{array}{l}\text { Dried bilberries or } 1 \text { or } 10 \% \\
\text { anthocyanins (ACs) }\end{array}$ & Anthocyanidin & 1 and $10 \% \mathrm{ACs}$ & $\begin{array}{l}\text { Acute and chronic dextrane sodium sulphate } \\
\text { (DSS) colitis of Balb/c mice }\end{array}$ & Amelioration of acute as well as chronic colitis & [131] \\
\hline $\begin{array}{l}\text { Mirtoselect, an anthocyanin mixture } \\
\text { from bilberry }\end{array}$ & Anthocyanidin & $0.1 \%$ and $0.3 \%(w / w)$ ACs in diet & $\begin{array}{l}\text { Apc(Min) mice, a genetic model of human } \\
\text { familial adenomatous polyposis }\end{array}$ & Reduced adenoma load dose-dependently & [135] \\
\hline Apigenin & Flavone & $50-80 \mu \mathrm{M}$ & $\begin{array}{l}\text { Human coloncarcinoma cell lines SW480, } \\
\text { HT-29, and Caco-2 }\end{array}$ & $\begin{array}{l}\text { Cell-cycle arrest at G2/M; p34(cdc2) and } \\
\text { decreased cyclin B1 protein expression }\end{array}$ & [143] \\
\hline $\begin{array}{l}\text { Apigenin analogs (acacetin, chrysin, } \\
\text { kampherol, luteolin, myricetin, } \\
\text { naringenin, and quercetin) }\end{array}$ & Flavone & $40-80 \mu \mathrm{M}$ & $\begin{array}{l}\text { Human SW480 and Caco-2 colonic } \\
\text { carcinoma cells }\end{array}$ & G2/M cell-cycle arrest & [144] \\
\hline Apigenin & Flavone & $20-80 \mu \mathrm{M}$ & HT29-APC cells & $\begin{array}{l}\text { G2/M cell-cycle arrest; induction of APC } \\
\text { protein expression }\end{array}$ & [145] \\
\hline Apigenin & Flavone & $\begin{array}{l}10 \mu \mathrm{M} \text { in vitro; } 25 \text { and } 50 \mathrm{mg} / \mathrm{kg} \\
\text { in vivo }\end{array}$ & $\begin{array}{l}\text { Human colorectal cancer cells HCT-116, } \\
\text { SW480, HT-29 and LoVo; APCMIN+ mice }\end{array}$ & Reduced polyp numbers; increased p53 activation & [148] \\
\hline Apigenin and quercetagetin & Flavone & $200 \mu \mathrm{M}$ & Human colorectal colon cancer (SW480) cells & $\begin{array}{l}\text { Inhibition of cell proliferation; alter the expression } \\
\text { of } b a x \text { and } b c l 2 \text { transcription }\end{array}$ & [149] \\
\hline Apigenin & Flavone & $50 \mu \mathrm{M}$ & HCT116 human colon cancer cells & Apoptosis- and autophagy-inducing effects & [146] \\
\hline Apigenin & Flavone & $1.5626-100 \mu \mathrm{M}$ & Colorectal cell lines HT-29 and HCT-15 & Pro-oxidative stress induction & [147] \\
\hline Apigenin & Flavone & $25-100 \mu \mathrm{g} / \mathrm{mL}$ & Human gut bacteria & $\begin{array}{l}\text { Inhibited Enterococcus caccae growth; up-regulated } \\
\text { genes involved in DNA repair, stress response, } \\
\text { cell wall synthesis, and protein folding }\end{array}$ & [165] \\
\hline Quercetin & Flavonol & & Human colon cancer COLO320 DM cells & Inhibited cell growth & [170] \\
\hline Quercetin and rutin & Flavonol & $2 \%$ quercetin; $4 \%$ rutin in diet & $\begin{array}{l}\text { Azoxymethane (AOM)-induced colonic } \\
\text { neoplasia in mice }\end{array}$ & $\begin{array}{l}\text { Reduced hyperproliferation of colonic epithelial } \\
\text { cells and focal areas of dysplasia (FAD) incidence }\end{array}$ & [175] \\
\hline Quercetin and rutin & Flavonol & $2 \%$ quercetin; $4 \%$ rutin in diet & AOM-induced colonic neoplasia in mice & Reduced FAD & [178] \\
\hline Quercetin & Flavonol & $25-100 \mu \mathrm{M}$ & HT-29 and SW480 colon cancer cells & $\begin{array}{l}\text { Inhibited cell growth and promoted apoptosis; } \\
\text { down-regulated ErbB2/ErbB3 signaling and } \\
\text { Akt pathway }\end{array}$ & [166] \\
\hline Quercetin & Flavonol & $5-50 \mu \mathrm{M}$ & Caco- 2 cells & $\begin{array}{l}\text { Induced cell cycle arrest; downregulated } \\
\text { expression of cell cycle genes }\end{array}$ & [168] \\
\hline Quercetin & Flavonol & $100 \mu \mathrm{M}$ & SW480 cells & $\begin{array}{c}\text { Inhibited the transcriptional activity of } \\
\beta \text {-catenin/Tcf }\end{array}$ & [172] \\
\hline
\end{tabular}


Table 2. Cont.

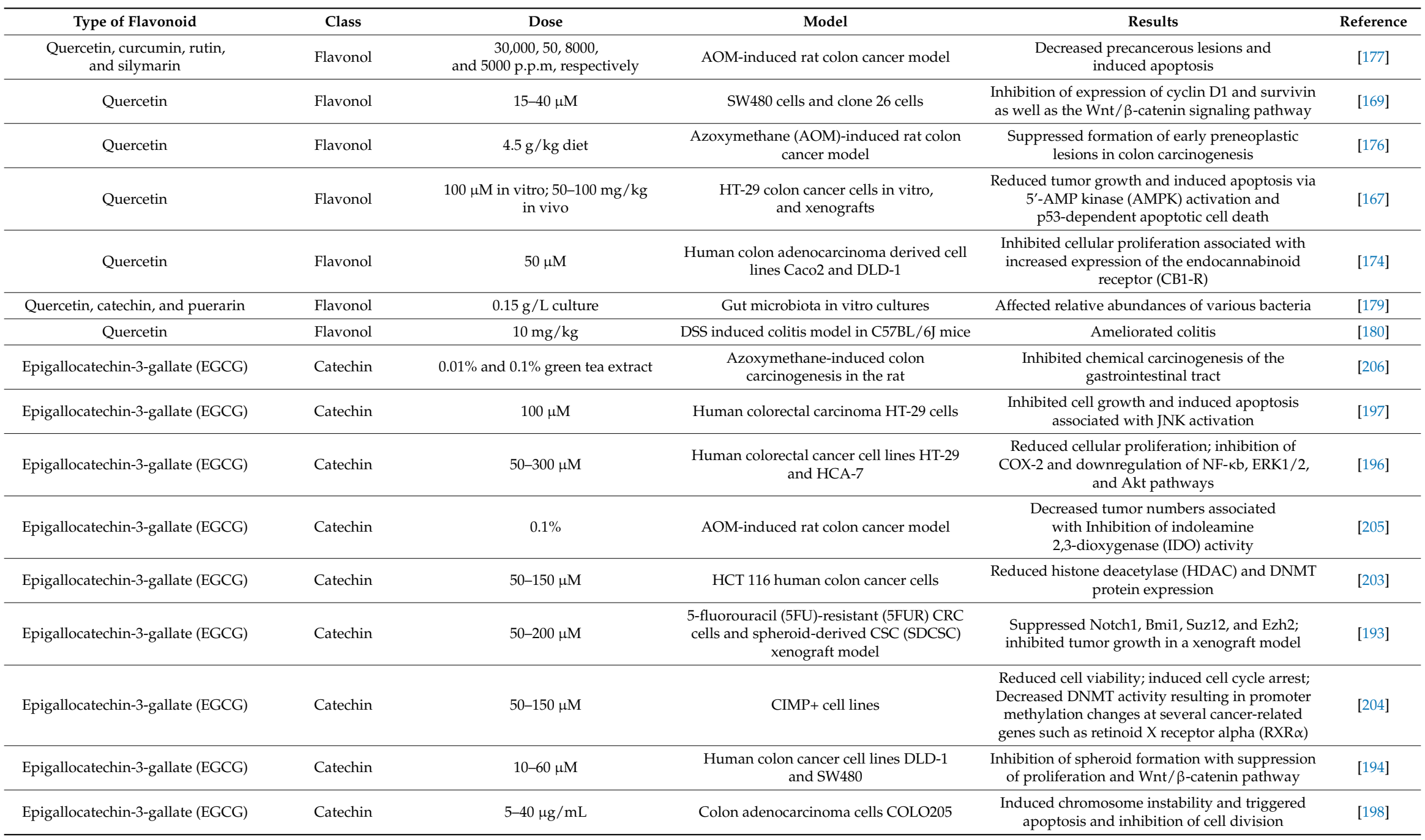

JNK: c-Jun N-terminal kinase; ERK: extracellular signal-regulated kinase; DNMT: DNA methyltransferase. 
Future studies that combine bacterial transcriptomics and metagenomics with metabolomics will, therefore, be critical in defining specific bacterial activities that are important for the generation of specific flavonoid bioactives or are altered by the ingestion of flavonoids. Studies involving fecal transplant of microbiota associated with the intake of specific flavonoids or the administration of synthetic bacterial communities effective in flavonoid metabolism in germfree mice will provide additional evidence that flavonoid-mediated changes in the gut microbiome can be beneficial to the host and regulate colorectal cancer susceptibility. The use of germfree mice will also be important in identifying microbiome-specific contributions to the anti-tumor effects of flavonoids. Since there is significant inter-individual heterogeneity in the composition of the gut microbiota [211], interventions to modulate the gut microbiome to enhance the efficacy of flavonoids or customizing the diet to enrich for specific flavonoids may be strategies that can be adopted in the future once a better understanding of the interrelationship between flavonoid bioactivity and the gut microbiota is achieved. Finally, the poor bioavailability and solubility of flavonoids makes their use as a potential chemopreventive drug challenging and will require novel strategies to optimize their delivery, dose, and metabolism. As flavonoids have potential anti-tumor effects not limited to colon cancer, advances made in our understanding of the function and metabolism of flavonoids may contribute significantly to the prevention of human cancers in general.

Funding: This research was funded by [U.S. Department of Agriculture] grant number [NIFA 2018-67017-27520] and [U.S. Department of Defense] grant number [CA170922].

Acknowledgments: The authors regret any work not cited due to space constraints. The authors would also like to thank Bo Wen for assistance with Figure 1.

Conflicts of Interest: The authors declare no conflict of interest.

\section{References}

1. Bray, F.; Ferlay, J.; Soerjomataram, I.; Siegel, R.L.; Torre, L.A.; Jemal, A. Global cancer statistics 2018: GLOBOCAN estimates of incidence and mortality worldwide for 36 cancers in 185 countries. CA Cancer J. Clin. 2018. [CrossRef] [PubMed]

2. Nishihara, R.; Wu, K.; Lochhead, P.; Morikawa, T.; Liao, X.; Qian, Z.R.; Inamura, K.; Kim, S.A.; Kuchiba, A.; Yamauchi, M.; et al. Long-term colorectal-cancer incidence and mortality after lower endoscopy. N. Engl. J. Med. 2013, 369, 1095-1105. [CrossRef] [PubMed]

3. U.S. Preventive Services Task Force; Bibbins-Domingo, K.; Grossman, D.C.; Curry, S.J.; Davidson, K.W.; Epling, J.W., Jr.; Garcia, F.A.R.; Gillman, M.W.; Harper, D.M.; Kemper, A.R.; et al. Screening for Colorectal Cancer: US Preventive Services Task Force Recommendation Statement. JAMA 2016, 315, 2564-2575. [PubMed]

4. Siegel, R.L.; Fedewa, S.A.; Anderson, W.F.; Miller, K.D.; Ma, J.; Rosenberg, P.S.; Jemal, A. Colorectal Cancer Incidence Patterns in the United States, 1974-2013. J. Natl. Cancer Inst. 2017, 109. [CrossRef] [PubMed]

5. Siegel, R.L.; Miller, K.D.; Fedewa, S.A.; Ahnen, D.J.; Meester, R.G.S.; Barzi, A.; Jemal, A. Colorectal cancer statistics, 2017. CA Cancer J. Clin. 2017, 67, 177-193. [CrossRef] [PubMed]

6. Fearon, E.R.; Vogelstein, B. A genetic model for colorectal tumorigenesis. Cell 1990, 61, 759-767. [CrossRef]

7. Tomasetti, C.; Marchionni, L.; Nowak, M.A.; Parmigiani, G.; Vogelstein, B. Only three driver gene mutations are required for the development of lung and colorectal cancers. Proc. Natl. Acad. Sci. USA 2015, 112, 118-123. [CrossRef] [PubMed]

8. Haggar, F.A.; Boushey, R.P. Colorectal cancer epidemiology: Incidence, mortality, survival, and risk factors. Clin. Colon Rectal Surg. 2009, 22, 191-197. [CrossRef] [PubMed]

9. Hanahan, D.; Weinberg, R.A. The hallmarks of cancer. Cell 2000, 100, 57-70. [CrossRef]

10. Hanahan, D.; Weinberg, R.A. Hallmarks of cancer: The next generation. Cell 2011, 144, 646-674. [CrossRef]

11. Lewis, J.D.; Deren, J.J.; Lichtenstein, G.R. Cancer risk in patients with inflammatory bowel disease. Gastroenterol. Clin. N. Am. 1999, 28, 459-477. [CrossRef]

12. World Cancer Research Fund International/American Institute for Cancer Research. Continuous Update Project Report: Diet, Nutrition, Physical Activity and Colorectal Cancer. 2017. Available online: Wcrf.org/colorectal-cancer-2017 (accessed on 1 September 2018). 
13. Turnbaugh, P.J.; Ridaura, V.K.; Faith, J.J.; Rey, F.E.; Knight, R.; Gordon, J.I. The effect of diet on the human gut microbiome: A metagenomic analysis in humanized gnotobiotic mice. Sci. Transl. Med. 2009, 1, 6 ra14. [CrossRef] [PubMed]

14. Carr, P.R.; Weigl, K.; Jansen, L.; Walter, V.; Erben, V.; Chang-Claude, J.; Brenner, H.; Hoffmeister, M. Healthy Lifestyle Factors Associated With Lower Risk of Colorectal Cancer Irrespective of Genetic Risk. Gastroenterology 2018. [CrossRef] [PubMed]

15. Kamada, N.; Seo, S.U.; Chen, G.Y.; Nunez, G. Role of the gut microbiota in immunity and inflammatory disease. Nat. Rev. Immunol. 2013, 13, 321-335. [CrossRef] [PubMed]

16. Kamada, N.; Chen, G.Y.; Inohara, N.; Nunez, G. Control of pathogens and pathobionts by the gut microbiota. Nat. Immunol. 2013, 14, 685-690. [CrossRef] [PubMed]

17. Hurtado, C.G.; Wan, F.; Housseau, F.; Sears, C.L. Roles for Interleukin 17 and Adaptive Immunity in Pathogenesis of Colorectal Cancer. Gastroenterology 2018. [CrossRef] [PubMed]

18. Silva, F.A.; Rodrigues, B.L.; Ayrizono, M.L.; Leal, R.F. The Immunological Basis of Inflammatory Bowel Disease. Gastroenterol. Res. Pract. 2016, 2016, 2097274. [CrossRef]

19. Louis, P.; Hold, G.L.; Flint, H.J. The gut microbiota, bacterial metabolites and colorectal cancer. Nat. Rev. Microbiol. 2014, 12, 661-672. [CrossRef]

20. Sobhani, I.; Tap, J.; Roudot-Thoraval, F.; Roperch, J.P.; Letulle, S.; Langella, P.; Corthier, G.; Tran Van Nhieu, J.; Furet, J.P. Microbial dysbiosis in colorectal cancer (CRC) patients. PLoS ONE 2011, 6, e16393. [CrossRef]

21. Marchesi, J.R.; Dutilh, B.E.; Hall, N.; Peters, W.H.; Roelofs, R.; Boleij, A.; Tjalsma, H. Towards the human colorectal cancer microbiome. PLoS ONE 2011, 6, e20447. [CrossRef]

22. Ahn, J.; Sinha, R.; Pei, Z.; Dominianni, C.; Wu, J.; Shi, J.; Goedert, J.J.; Hayes, R.B.; Yang, L. Human gut microbiome and risk for colorectal cancer. J. Natl. Cancer Inst. 2013, 105, 1907-1911. [CrossRef] [PubMed]

23. Wang, T.; Cai, G.; Qiu, Y.; Fei, N.; Zhang, M.; Pang, X.; Jia, W.; Cai, S.; Zhao, L. Structural segregation of gut microbiota between colorectal cancer patients and healthy volunteers. ISME J. 2012, 6, 320-329. [CrossRef] [PubMed]

24. Zackular, J.P.; Rogers, M.A.; Ruffin, M.T.T.; Schloss, P.D. The human gut microbiome as a screening tool for colorectal cancer. Cancer Prev. Res. (Phila.) 2014, 7, 1112-1121. [CrossRef] [PubMed]

25. Kostic, A.D.; Gevers, D.; Pedamallu, C.S.; Michaud, M.; Duke, F.; Earl, A.M.; Ojesina, A.I.; Jung, J.; Bass, A.J.; Tabernero, J.; et al. Genomic analysis identifies association of Fusobacterium with colorectal carcinoma. Genome Res. 2012, 22, 292-298. [CrossRef] [PubMed]

26. Drewes, J.L.; White, J.R.; Dejea, C.M.; Fathi, P.; Iyadorai, T.; Vadivelu, J.; Roslani, A.C.; Wick, E.C.; Mongodin, E.F.; Loke, M.F.; et al. High-resolution bacterial 16S rRNA gene profile meta-analysis and biofilm status reveal common colorectal cancer consortia. NPJ Biofilms Microbiomes 2017, 3, 34. [CrossRef]

27. Zackular, J.P.; Baxter, N.T.; Iverson, K.D.; Sadler, W.D.; Petrosino, J.F.; Chen, G.Y.; Schloss, P.D. The gut microbiome modulates colon tumorigenesis. MBio 2013, 4. [CrossRef]

28. Seregin, S.S.; Golovchenko, N.; Schaf, B.; Chen, J.; Pudlo, N.A.; Mitchell, J.; Baxter, N.T.; Zhao, L.; Schloss, P.D.; Martens, E.C.; et al. NLRP6 Protects Il10(-/-) Mice from Colitis by Limiting Colonization of Akkermansia muciniphila. Cell Rep. 2017, 19, 733-745. [CrossRef]

29. Schwabe, R.F.; Jobin, C. The microbiome and cancer. Nat. Rev. Cancer 2013, 13, 800-812. [CrossRef]

30. Lee, S.H.; Yun, Y.; Kim, S.J.; Lee, E.J.; Chang, Y.; Ryu, S.; Shin, H.; Kim, H.L.; Kim, H.N.; Lee, J.H. Association between Cigarette Smoking Status and Composition of Gut Microbiota: Population-Based Cross-Sectional Study. J. Clin. Med. 2018, 7, 282. [CrossRef]

31. Aune, D.; Giovannucci, E.; Boffetta, P.; Fadnes, L.T.; Keum, N.; Norat, T.; Greenwood, D.C.; Riboli, E.; Vatten, L.J.; Tonstad, S. Fruit and vegetable intake and the risk of cardiovascular disease, total cancer and all-cause mortality-a systematic review and dose-response meta-analysis of prospective studies. Int. J. Epidemiol. 2017, 46, 1029-1056. [CrossRef]

32. Van Duijnhoven, F.J.; Bueno-De-Mesquita, H.B.; Ferrari, P.; Jenab, M.; Boshuizen, H.C.; Ros, M.M.; Casagrande, C.; Tjonneland, A.; Olsen, A.; Overvad, K.; et al. Fruit, vegetables, and colorectal cancer risk: The European Prospective Investigation into Cancer and Nutrition. Am. J. Clin. Nutr. 2009, 89, 1441-1452. [CrossRef] [PubMed]

33. Luo, W.P.; Fang, Y.J.; Lu, M.S.; Zhong, X.; Chen, Y.M.; Zhang, C.X. High consumption of vegetable and fruit colour groups is inversely associated with the risk of colorectal cancer: A case-control study. Br. J. Nutr. 2015, 113, 1129-1138. [CrossRef] 
34. Chang, H.; Lei, L.; Zhou, Y.; Ye, F.; Zhao, G. Dietary Flavonoids and the Risk of Colorectal Cancer: An Updated Meta-Analysis of Epidemiological Studies. Nutrients 2018, 10, 950. [CrossRef] [PubMed]

35. Manach, C.; Scalbert, A.; Morand, C.; Remesy, C.; Jimenez, L. Polyphenols: Food sources and bioavailability. Am. J. Clin. Nutr. 2004, 79, 727-747. [CrossRef] [PubMed]

36. Mierziak, J.; Kostyn, K.; Kulma, A. Flavonoids as important molecules of plant interactions with the environment. Molecules 2014, 19, 16240-16265. [CrossRef] [PubMed]

37. Cardona, F.; Andres-Lacueva, C.; Tulipani, S.; Tinahones, F.J.; Queipo-Ortuno, M.I. Benefits of polyphenols on gut microbiota and implications in human health. J. Nutr. Biochem. 2013, 24, 1415-1422. [CrossRef] [PubMed]

38. Kawser Hossain, M.; Abdal Dayem, A.; Han, J.; Yin, Y.; Kim, K.; Kumar Saha, S.; Yang, G.M.; Choi, H.Y.; Cho, S.G. Molecular Mechanisms of the Anti-Obesity and Anti-Diabetic Properties of Flavonoids. Int. J. Mol. Sci. 2016, 17, 569. [CrossRef]

39. Charepalli, V.; Reddivari, L.; Vadde, R.; Walia, S.; Radhakrishnan, S.; Vanamala, J.K. Eugenia jambolana (Java Plum) Fruit Extract Exhibits Anti-Cancer Activity against Early Stage Human HCT-116 Colon Cancer Cells and Colon Cancer Stem Cells. Cancers 2016, 8, 29. [CrossRef]

40. Khan, M.K.; Huma, Z.E.; Dangles, O. A comprehensive review on flavanones, the major citrus polyphenols. J. Food Compos. Anal. 2014, 33, 85-104. [CrossRef]

41. Kang, H.W.; Lee, S.G.; Otieno, D.; Ha, K. Flavonoids, Potential Bioactive Compounds, and Non-Shivering Thermogenesis. Nutrients 2018, 10, 1168. [CrossRef]

42. Zhao, Y.; Hu, X.; Zuo, X.; Wang, M. Chemopreventive effects of some popular phytochemicals on human colon cancer: A review. Food Funct. 2018. [CrossRef] [PubMed]

43. Brodowska, F.M. Natural flavonoids: Classification, potential role, and application of flavonoid analogues. Eur. J. Biol. Res. 2017, 7, 108-123.

44. Hostetler, G.L.; Ralston, R.A.; Schwartz, S.J. Flavones: Food Sources, Bioavailability, Metabolism, and Bioactivity. Adv. Nutr. 2017, 8, 423-435. [CrossRef] [PubMed]

45. Ganjare, A.B.; Nirmal, S.A.; Patil, A.N. Use of apigenin from Cordia dichotoma in the treatment of colitis. Fitoterapia 2011, 82, 1052-1056. [CrossRef] [PubMed]

46. Tungmunnithum, D.; Thongboonyou, A.; Pholboon, A.; Yangsabai, A. Flavonoids and Other Phenolic Compounds from Medicinal Plants for Pharmaceutical and Medical Aspects: An Overview. Medicines 2018, 5, 93. [CrossRef]

47. Hanske, L.; Loh, G.; Sczesny, S.; Blaut, M.; Braune, A. The bioavailability of apigenin-7-glucoside is influenced by human intestinal microbiota in rats. J. Nutr. 2009, 139, 1095-1102. [CrossRef] [PubMed]

48. Bodet, C.; La, V.D.; Epifano, F.; Grenier, D. Naringenin has anti-inflammatory properties in macrophage and ex vivo human whole-blood models. J. Periodontal Res. 2008, 43, 400-407. [CrossRef]

49. Kumar, S.; Pandey, A.K. Chemistry and biological activities of flavonoids: An overview. Sci. World J. 2013, 2013, 162750. [CrossRef]

50. Marotti, I.; Bonetti, A.; Biavati, B.; Catizone, P.; Dinelli, G. Biotransformation of common bean (Phaseolus vulgaris L.) flavonoid glycosides by bifidobacterium species from human intestinal origin. J. Agric. Food Chem. 2007, 55, 3913-3919. [CrossRef]

51. Zahoor, M.; Shafiq, S.; Ullah, H.; Sadiq, A.; Ullah, F. Isolation of quercetin and mandelic acid from Aesculus indica fruit and their biological activities. BMC Biochem. 2018, 19, 5. [CrossRef]

52. Hashemzaei, M.; Delarami Far, A.; Yari, A.; Heravi, R.E.; Tabrizian, K.; Taghdisi, S.M.; Sadegh, S.E.; Tsarouhas, K.; Kouretas, D.; Tzanakakis, G.; et al. Anticancer and apoptosisinducing effects of quercetin in vitro and in vivo. Oncol. Rep. 2017, 38, 819-828. [CrossRef] [PubMed]

53. Nwaeburu, C.C.; Abukiwan, A.; Zhao, Z.; Herr, I. Quercetin-induced miR-200b-3p regulates the mode of self-renewing divisions in pancreatic cancer. Mol. Cancer 2017, 16, 23. [CrossRef] [PubMed]

54. Yang, X.; Zhang, W.; Zhao, Z.; Li, N.; Mou, Z.; Sun, D.; Cai, Y.; Wang, W.; Lin, Y. Quercetin loading CdSe/ZnS nanoparticles as efficient antibacterial and anticancer materials. J. Inorg. Biochem. 2017, 167, 36-48. [CrossRef] [PubMed]

55. Chen, A.Y.; Chen, Y.C. A review of the dietary flavonoid, kaempferol on human health and cancer chemoprevention. Food Chem. 2013, 138, 2099-2107. [CrossRef] [PubMed]

56. Semwal, D.K.; Semwal, R.B.; Combrinck, S.; Viljoen, A. Myricetin: A Dietary Molecule with Diverse Biological Activities. Nutrients 2016, 8, 90. [CrossRef] [PubMed] 
57. Yao, Y.; Lin, G.; Xie, Y.; Ma, P.; Li, G.; Meng, Q.; Wu, T. Preformulation studies of myricetin: A natural antioxidant flavonoid. Pharmazie 2014, 69, 19-26. [PubMed]

58. Li, C.; Yang, X.; Chen, C.; Cai, S.; Hu, J. Isorhamnetin suppresses colon cancer cell growth through the PI3KAktmTOR pathway. Mol. Med. Rep. 2014, 9, 935-940. [CrossRef] [PubMed]

59. Bao, M.; Lou, Y. Isorhamnetin prevent endothelial cell injuries from oxidized LDL via activation of p38MAPK. Eur. J. Pharmacol. 2006, 547, 22-30. [CrossRef]

60. Ma, G.; Yang, C.; Qu, Y.; Wei, H.; Zhang, T.; Zhang, N. The flavonoid component isorhamnetin in vitro inhibits proliferation and induces apoptosis in Eca-109 cells. Chem. Biol. Interact. 2007, 167, 153-160. [CrossRef]

61. Kim, J.E.; Lee, D.E.; Lee, K.W.; Son, J.E.; Seo, S.K.; Li, J.; Jung, S.K.; Heo, Y.S.; Mottamal, M.; Bode, A.M.; et al. Isorhamnetin suppresses skin cancer through direct inhibition of MEK1 and PI3-K. Cancer Prev. Res. (Phila.) 2011, 4, 582-591. [CrossRef]

62. Murphy, P.A.; Song, T.; Buseman, G.; Barua, K.; Beecher, G.R.; Trainer, D.; Holden, J. Isoflavones in retail and institutional soy foods. J. Agric. Food Chem. 1999, 47, 2697-2704. [CrossRef] [PubMed]

63. Mukund, V.; Mukund, D.; Sharma, V.; Mannarapu, M.; Alam, A. Genistein: Its role in metabolic diseases and cancer. Crit. Rev. Oncol. Hematol. 2017, 119, 13-22. [CrossRef] [PubMed]

64. Applegate, C.C.; Rowles, J.L.; Ranard, K.M.; Jeon, S.; Erdman, J.W. Soy Consumption and the Risk of Prostate Cancer: An Updated Systematic Review and Meta-Analysis. Nutrients 2018, 10, 40. [CrossRef] [PubMed]

65. Khoo, H.E.; Azlan, A.; Tang, S.T.; Lim, S.M. Anthocyanidins and anthocyanins: Colored pigments as food, pharmaceutical ingredients, and the potential health benefits. Food Nutr. Res. 2017, 61, 1361779. [CrossRef] [PubMed]

66. Huang, W.Y.; Liu, Y.M.; Wang, J.; Wang, X.N.; Li, C.Y. Anti-inflammatory effect of the blueberry anthocyanins malvidin-3-glucoside and malvidin-3-galactoside in endothelial cells. Molecules 2014, 19, 12827-12841. [CrossRef] [PubMed]

67. Huang, W.; Zhu, Y.; Li, C.; Sui, Z.; Min, W. Effect of Blueberry Anthocyanins Malvidin and Glycosides on the Antioxidant Properties in Endothelial Cells. Oxid. Med. Cell Longev. 2016, 2016, 1591803. [CrossRef] [PubMed]

68. Kovinich, N.; Kayanja, G.; Chanoca, A.; Riedl, K.; Otegui, M.S.; Grotewold, E. Not all anthocyanins are born equal: Distinct patterns induced by stress in Arabidopsis. Planta 2014, 240, 931-940. [CrossRef]

69. Takanori, T.; Fumihiko, H.; Kaji, U.; Hiromitsu, A.; Thoshihiko, O. Dietary cyanidin 3-O-beta-D-glucoside rich purple corn color prevents obesity and ameliorates hyperglycemia in mice. J. Nutr. 2003, 133, 2125-2130.

70. Edirisinghe, I.; Banaszewski, K.; Cappozzo, J.; Sandhya, K.; Ellis, C.L.; Tadapaneni, R.; Kappagoda, C.T.; Burton-Freeman, B.M. Strawberry anthocyanin and its association with postprandial inflammation and insulin. Br. J. Nutr. 2011, 106, 913-922. [CrossRef]

71. Thilakarathna, S.H.; Rupasinghe, H.P. Flavonoid bioavailability and attempts for bioavailability enhancement. Nutrients 2013, 5, 3367-3387. [CrossRef]

72. Pajak, P.; Socha, R.; Galkowska, D.; Roznowski, J.; Fortuna, T. Phenolic profile and antioxidant activity in selected seeds and sprouts. Food Chem. 2014, 143, 300-306. [CrossRef] [PubMed]

73. Hein, E.M.; Rose, K.; van't Slot, G.; Friedrich, A.W.; Humpf, H.U. Deconjugation and degradation of flavonol glycosides by pig cecal microbiota characterized by Fluorescence in situ hybridization (FISH). J. Agric. Food Chem. 2008, 56, 2281-2290. [CrossRef] [PubMed]

74. Vollmer, M.; Esders, S.; Farquharson, F.M.; Neugart, S.; Duncan, S.H.; Schreiner, M.; Louis, P.; Maul, R.; Rohn, S. Mutual Interaction of Phenolic Compounds and Microbiota: Metabolism of Complex Phenolic Apigenin-C- and Kaempferol-O-Derivatives by Human Fecal Samples. J. Agric. Food Chem. 2018, 66, 485-497. [CrossRef] [PubMed]

75. Braune, A.; Blaut, M. Bacterial species involved in the conversion of dietary flavonoids in the human gut. Gut Microbes 2016, 7, 216-234. [CrossRef] [PubMed]

76. Manach, C.; Morand, C.; Demigne, C.; Texier, O.; Regerat, F.; Remesy, C. Bioavailability of rutin and quercetin in rats. FEBS Lett. 1997, 409, 12-16. [CrossRef]

77. Murota, K.; Shimizu, S.; Miyamoto, S.; Izumi, T.; Obata, A.; Kikuchi, M.; Terao, J. Unique uptake and transport of isoflavone aglycones by human intestinal caco-2 cells: Comparison of isoflavonoids and flavonoids. J. Nutr. 2002, 132, 1956-1961. [CrossRef] [PubMed] 
78. Boyer, J.; Brown, D.; Liu, R.H. Uptake of quercetin and quercetin 3-glucoside from whole onion and apple peel extracts by Caco-2 cell monolayers. J. Agric. Food Chem. 2004, 52, 7172-7179. [CrossRef]

79. Gonzalez-Paramas, A.M.; Ayuda-Duran, B.; Martinez, S.; Gonzalez-Manzano, S.; Santos-Buelga, C. The Mechanisms behind the Biological Activity of Flavonoids. Curr. Med. Chem. 2018. [CrossRef] [PubMed]

80. Day, A.J.; Canada, F.J.; Diaz, J.C.; Kroon, P.A.; McLauchlan, R.; Faulds, C.B.; Plumb, G.W.; Morgan, M.R.; Williamson, G. Dietary flavonoid and isoflavone glycosides are hydrolysed by the lactase site of lactase phlorizin hydrolase. FEBS Lett. 2000, 468, 166-170. [CrossRef]

81. Nemeth, K.; Plumb, G.W.; Berrin, J.G.; Juge, N.; Jacob, R.; Naim, H.Y.; Williamson, G.; Swallow, D.M.; Kroon, P.A. Deglycosylation by small intestinal epithelial cell beta-glucosidases is a critical step in the absorption and metabolism of dietary flavonoid glycosides in humans. Eur. J. Nutr. 2003, 42, $29-42$. [CrossRef] [PubMed]

82. Murota, K.; Nakamura, Y.; Uehara, M. Flavonoid metabolism: The interaction of metabolites and gut microbiota. Biosci. Biotechnol. Biochem. 2018, 82, 600-610. [CrossRef] [PubMed]

83. Day, A.J.; DuPont, M.S.; Ridley, S.; Rhodes, M.; Rhodes, M.J.; Morgan, M.R.; Williamson, G. Deglycosylation of flavonoid and isoflavonoid glycosides by human small intestine and liver beta-glucosidase activity. FEBS Lett. 1998, 436, 71-75. [CrossRef]

84. Van der Woude, H.; Boersma, M.G.; Vervoort, J.; Rietjens, I.M. Identification of 14 quercetin phase II mono- and mixed conjugates and their formation by rat and human phase II in vitro model systems. Chem. Res. Toxicol. 2004, 17, 1520-1530. [CrossRef] [PubMed]

85. Piskula, M.K.; Terao, J. Accumulation of (-)-epicatechin metabolites in rat plasma after oral administration and distribution of conjugation enzymes in rat tissues. J. Nutr. 1998, 128, 1172-1178. [CrossRef]

86. Mullen, W.; Edwards, C.A.; Crozier, A. Absorption, excretion and metabolite profiling of methyl-, glucuronyl-, glucosyl- and sulpho-conjugates of quercetin in human plasma and urine after ingestion of onions. Br. J. Nutr. 2006, 96, 107-116. [CrossRef] [PubMed]

87. O'Leary, K.A.; Day, A.J.; Needs, P.W.; Mellon, F.A.; O’Brien, N.M.; Williamson, G. Metabolism of quercetin-7and quercetin-3-glucuronides by an in vitro hepatic model: The role of human beta-glucuronidase, sulfotransferase, catechol-O-methyltransferase and multi-resistant protein 2 (MRP2) in flavonoid metabolism. Biochem. Pharmacol. 2003, 65, 479-491. [CrossRef]

88. Crozier, A.; Del Rio, D.; Clifford, M.N. Bioavailability of dietary flavonoids and phenolic compounds. Mol. Aspects Med. 2010, 31, 446-467. [CrossRef]

89. Clarke, D.B.; Lloyd, A.S.; Botting, N.P.; Oldfield, M.F.; Needs, P.W.; Wiseman, H. Measurement of intact sulfate and glucuronide phytoestrogen conjugates in human urine using isotope dilution liquid chromatography-tandem mass spectrometry with [13C(3)]isoflavone internal standards. Anal. Biochem. 2002, 309, 158-172. [CrossRef]

90. Nakamura, T.; Murota, K.; Kumamoto, S.; Misumi, K.; Bando, N.; Ikushiro, S.; Takahashi, N.; Sekido, K.; Kato, Y.; Terao, J. Plasma metabolites of dietary flavonoids after combination meal consumption with onion and tofu in humans. Mol. Nutr. Food Res. 2014, 58, 310-317. [CrossRef]

91. Arts, I.C.; Sesink, A.L.; Faassen-Peters, M.; Hollman, P.C. The type of sugar moiety is a major determinant of the small intestinal uptake and subsequent biliary excretion of dietary quercetin glycosides. Br. J. Nutr. 2004, 91, 841-847. [CrossRef]

92. Adlercreutz, H.; Hockerstedt, K.; Bannwart, C.; Bloigu, S.; Hamalainen, E.; Fotsis, T.; Ollus, A. Effect of dietary components, including lignans and phytoestrogens, on enterohepatic circulation and liver metabolism of estrogens and on sex hormone binding globulin (SHBG). J. Steroid. Biochem. 1987, 27, 1135-1144. [CrossRef]

93. Tomas-Barberan, F.A.; Selma, M.V.; Espin, J.C. Interactions of gut microbiota with dietary polyphenols and consequences to human health. Curr. Opin. Clin. Nutr. Metab. Care 2016, 19, 471-476. [CrossRef] [PubMed]

94. Feng, X.; Li, Y.; Brobbey Oppong, M.; Qiu, F. Insights into the intestinal bacterial metabolism of flavonoids and the bioactivities of their microbe-derived ring cleavage metabolites. Drug Metab. Rev. 2018, 1-14. [CrossRef] [PubMed]

95. Forester, S.C.; Choy, Y.Y.; Waterhouse, A.L.; Oteiza, P.I. The anthocyanin metabolites gallic acid, 3-O-methylgallic acid, and 2,4,6-trihydroxybenzaldehyde decrease human colon cancer cell viability by regulating pro-oncogenic signals. Mol. Carcinog. 2014, 53, 432-439. [CrossRef] [PubMed] 
96. Forester, S.C.; Waterhouse, A.L. Gut metabolites of anthocyanins, gallic acid, 3-O-methylgallic acid, and 2,4,6-trihydroxybenzaldehyde, inhibit cell proliferation of Caco-2 cells. J. Agric. Food Chem. 2010, 58, 5320-5327. [CrossRef] [PubMed]

97. Gross, G.; Jacobs, D.M.; Peters, S.; Possemiers, S.; van Duynhoven, J.; Vaughan, E.E.; van de Wiele, T. In vitro bioconversion of polyphenols from black tea and red wine/grape juice by human intestinal microbiota displays strong interindividual variability. J. Agric. Food Chem. 2010, 58, 10236-10246. [CrossRef] [PubMed]

98. Raimondi, S.; Roncaglia, L.; De Lucia, M.; Amaretti, A.; Leonardi, A.; Pagnoni, U.M.; Rossi, M. Bioconversion of soy isoflavones daidzin and daidzein by Bifidobacterium strains. Appl. Microbiol. Biotechnol. 2009, 81, 943-950. [CrossRef] [PubMed]

99. Bang, S.H.; Hyun, Y.J.; Shim, J.; Hong, S.W.; Kim, D.H. Metabolism of rutin and poncirin by human intestinal microbiota and cloning of their metabolizing alpha-L-rhamnosidase from Bifidobacterium dentium. J. Microbiol. Biotechnol. 2015, 25, 18-25. [CrossRef] [PubMed]

100. Schneider, H.; Schwiertz, A.; Collins, M.D.; Blaut, M. Anaerobic transformation of quercetin-3-glucoside by bacteria from the human intestinal tract. Arch. Microbiol. 1999, 171, 81-91. [CrossRef] [PubMed]

101. Liu, Y.; Liu, Y.; Dai, Y.; Xun, L.; Hu, M. Enteric disposition and recycling of flavonoids and ginkgo flavonoids. J. Altern. Complement. Med. 2003, 9, 631-640. [CrossRef] [PubMed]

102. Shin, N.R.; Moon, J.S.; Shin, S.Y.; Li, L.; Lee, Y.B.; Kim, T.J.; Han, N.S. Isolation and characterization of human intestinal Enterococcus avium EFEL009 converting rutin to quercetin. Lett. Appl. Microbiol. 2016, 62, 68-74. [CrossRef] [PubMed]

103. Kim, M.; Lee, J.; Han, J. Deglycosylation of isoflavone C-glycosides by newly isolated human intestinal bacteria. J. Sci. Food Agric. 2015, 95, 1925-1931. [CrossRef] [PubMed]

104. Braune, A.; Blaut, M. Intestinal bacterium Eubacterium cellulosolvens deglycosylates flavonoid C- and O-glucosides. Appl. Environ. Microbiol. 2012, 78, 8151-8153. [CrossRef] [PubMed]

105. Braune, A.; Blaut, M. Deglycosylation of puerarin and other aromatic C-glucosides by a newly isolated human intestinal bacterium. Environ. Microbiol. 2011, 13, 482-494. [CrossRef] [PubMed]

106. Jin, J.S.; Nishihata, T.; Kakiuchi, N.; Hattori, M. Biotransformation of C-glucosylisoflavone puerarin to estrogenic (3S)-equol in co-culture of two human intestinal bacteria. Biol. Pharm. Bull. 2008, 31, 1621-1625. [CrossRef] [PubMed]

107. Xu, J.; Qian, D.; Jiang, S.; Guo, J.; Shang, E.X.; Duan, J.A.; Yang, J. Application of ultra-performance liquid chromatography coupled with quadrupole time-of-flight mass spectrometry to determine the metabolites of orientin produced by human intestinal bacteria. J. Chromatogr. B Analyt. Technol. Biomed. Life Sci. 2014, 944, 123-127. [CrossRef] [PubMed]

108. Kim, M.; Kim, N.; Han, J. Metabolism of Kaempferia parviflora polymethoxyflavones by human intestinal bacterium Bautia sp. MRG-PMF1. J. Agric. Food Chem. 2014, 62, 12377-12383. [CrossRef] [PubMed]

109. Possemiers, S.; Heyerick, A.; Robbens, V.; De Keukeleire, D.; Verstraete, W. Activation of proestrogens from hops (Humulus lupulus L.) by intestinal microbiota; conversion of isoxanthohumol into 8-prenylnaringenin. J. Agric. Food Chem. 2005, 53, 6281-6288. [CrossRef]

110. Possemiers, S.; Rabot, S.; Espin, J.C.; Bruneau, A.; Philippe, C.; Gonzalez-Sarrias, A.; Heyerick, A.; Tomas-Barberan, F.A.; De Keukeleire, D.; Verstraete, W. Eubacterium limosum activates isoxanthohumol from hops (Humulus lupulus L.) into the potent phytoestrogen 8-prenylnaringenin in vitro and in rat intestine. J. Nutr. 2008, 138, 1310-1316. [CrossRef]

111. Hur, H.; Rafii, F. Biotransformation of the isoflavonoids biochanin A, formononetin, and glycitein by Eubacterium limosum. FEMS Microbiol. Lett. 2000, 192, 21-25. [CrossRef]

112. Wang, L.Q.; Meselhy, M.R.; Li, Y.; Nakamura, N.; Min, B.S.; Qin, G.W.; Hattori, M. The heterocyclic ring fission and dehydroxylation of catechins and related compounds by Eubacterium sp. strain SDG-2, a human intestinal bacterium. Chem. Pharm. Bull. (Tokyo.) 2001, 49, 1640-1643. [CrossRef] [PubMed]

113. Zhao, M.; Du, L.; Tao, J.; Qian, D.; Shang, E.X.; Jiang, S.; Guo, J.; Liu, P.; Su, S.L.; Duan, J.A. Determination of metabolites of diosmetin-7-O-glucoside by a newly isolated Escherichia coli from human gut using UPLC-Q-TOF/MS. J. Agric. Food Chem. 2014, 62, 11441-11448. [CrossRef] [PubMed]

114. Maruo, T.; Sakamoto, M.; Ito, C.; Toda, T.; Benno, Y. Adlercreutzia equolifaciens gen. nov., sp. nov., an equol-producing bacterium isolated from human faeces, and emended description of the genus Eggerthella. Int. J. Syst. Evol. Microbiol. 2008, 58, 1221-1227. [CrossRef] [PubMed] 
115. Kutschera, M.; Engst, W.; Blaut, M.; Braune, A. Isolation of catechin-converting human intestinal bacteria. J. Appl. Microbiol. 2011, 111, 165-175. [CrossRef] [PubMed]

116. Winter, J.; Popoff, M.R.; Grimont, P.; Bokkenheuser, V.D. Clostridium orbiscindens sp. nov., a human intestinal bacterium capable of cleaving the flavonoid C-ring. Int. J. Syst. Bacteriol. 1991, 41, 355-357. [CrossRef]

117. Braune, A.; Engst, W.; Blaut, M. Degradation of neohesperidin dihydrochalcone by human intestinal bacteria. J. Agric. Food Chem. 2005, 53, 1782-1790. [CrossRef] [PubMed]

118. Schoefer, L.; Mohan, R.; Braune, A.; Birringer, M.; Blaut, M. Anaerobic C-ring cleavage of genistein and daidzein by Eubacterium ramulus. FEMS Microbiol. Lett. 2002, 208, 197-202. [CrossRef] [PubMed]

119. Schoefer, L.; Mohan, R.; Schwiertz, A.; Braune, A.; Blaut, M. Anaerobic degradation of flavonoids by Clostridium orbiscindens. Appl. Environ. Microbiol. 2003, 69, 5849-5854. [CrossRef] [PubMed]

120. Braune, A.; Gutschow, M.; Engst, W.; Blaut, M. Degradation of quercetin and luteolin by Eubacterium ramulus. Appl. Environ. Microbiol. 2001, 67, 5558-5567. [CrossRef]

121. Schneider, H.; Blaut, M. Anaerobic degradation of flavonoids by Eubacterium ramulus. Arch. Microbiol. 2000, 173, 71-75. [CrossRef]

122. Singh, N.; Gurav, A.; Sivaprakasam, S.; Brady, E.; Padia, R.; Shi, H.; Thangaraju, M.; Prasad, P.D.; Manicassamy, S.; Munn, D.H.; et al. Activation of Gpr109a, receptor for niacin and the commensal metabolite butyrate, suppresses colonic inflammation and carcinogenesis. Immunity 2014, 40, 128-139. [CrossRef] [PubMed]

123. Tian, Y.; Xu, Q.; Sun, L.; Ye, Y.; Ji, G. Short-chain fatty acids administration is protective in colitis-associated colorectal cancer development. J. Nutr. Biochem. 2018, 57, 103-109. [CrossRef] [PubMed]

124. Seong, A.R.; Yoo, J.Y.; Choi, K.; Lee, M.H.; Lee, Y.H.; Lee, J.; Jun, W.; Kim, S.; Yoon, H.G. Delphinidin, a specific inhibitor of histone acetyltransferase, suppresses inflammatory signaling via prevention of NF-kappaB acetylation in fibroblast-like synoviocyte MH7A cells. Biochem. Biophys. Res. Commun. 2011, 410, 581-586. [CrossRef] [PubMed]

125. Ozbay, T.; Nahta, R. Delphinidin Inhibits HER2 and Erk1/2 Signaling and Suppresses Growth of HER2-Overexpressing and Triple Negative Breast Cancer Cell Lines. Breast Cancer (Auckl.) 2011, 5, 143-154. [CrossRef] [PubMed]

126. Kwon, J.Y.; Lee, K.W.; Hur, H.J.; Lee, H.J. Peonidin inhibits phorbol-ester-induced COX-2 expression and transformation in JB6 P+ cells by blocking phosphorylation of ERK-1 and -2. Ann. N. Y. Acad. Sci. 2007, 1095, 513-520. [CrossRef]

127. White, B.D.; Chien, A.J.; Dawson, D.W. Dysregulation of Wnt/beta-catenin signaling in gastrointestinal cancers. Gastroenterology 2012, 142, 219-232. [CrossRef]

128. Cvorovic, J.; Tramer, F.; Granzotto, M.; Candussio, L.; Decorti, G.; Passamonti, S. Oxidative stress-based cytotoxicity of delphinidin and cyanidin in colon cancer cells. Arch. Biochem. Biophys. 2010, 501, 151-157. [CrossRef]

129. Rowan, A.J.; Lamlum, H.; Ilyas, M.; Wheeler, J.; Straub, J.; Papadopoulou, A.; Bicknell, D.; Bodmer, W.F.; Tomlinson, I.P. APC mutations in sporadic colorectal tumors: A mutational "hotspot" and interdependence of the "two hits". Proc. Natl. Acad. Sci. USA 2000, 97, 3352-3357. [CrossRef]

130. Yun, J.M.; Afaq, F.; Khan, N.; Mukhtar, H. Delphinidin, an anthocyanidin in pigmented fruits and vegetables, induces apoptosis and cell cycle arrest in human colon cancer HCT116 cells. Mol. Carcinog. 2009, 48, 260-270. [CrossRef]

131. Piberger, H.; Oehme, A.; Hofmann, C.; Dreiseitel, A.; Sand, P.G.; Obermeier, F.; Schoelmerich, J.; Schreier, P.; Krammer, G.; Rogler, G. Bilberries and their anthocyanins ameliorate experimental colitis. Mol. Nutr. Food Res. 2011, 55, 1724-1729. [CrossRef]

132. De Robertis, M.; Massi, E.; Poeta, M.L.; Carotti, S.; Morini, S.; Cecchetelli, L.; Signori, E.; Fazio, V.M. The AOM/DSS murine model for the study of colon carcinogenesis: From pathways to diagnosis and therapy studies. J. Carcinog. 2011, 10, 9. [CrossRef] [PubMed]

133. Chen, L.; Jiang, B.; Zhong, C.; Guo, J.; Zhang, L.; Mu, T.; Zhang, Q.; Bi, X. Chemoprevention of colorectal cancer by black raspberry anthocyanins involved the modulation of gut microbiota and SFRP2 demethylation. Carcinogenesis 2018, 39, 471-481. [CrossRef] [PubMed] 
134. Wang, L.S.; Kuo, C.T.; Cho, S.J.; Seguin, C.; Siddiqui, J.; Stoner, K.; Weng, Y.I.; Huang, T.H.; Tichelaar, J.; Yearsley, M.; et al. Black raspberry-derived anthocyanins demethylate tumor suppressor genes through the inhibition of DNMT1 and DNMT3B in colon cancer cells. Nutr. Cancer 2013, 65, 118-125. [CrossRef] [PubMed]

135. Cooke, D.; Schwarz, M.; Boocock, D.; Winterhalter, P.; Steward, W.P.; Gescher, A.J.; Marczylo, T.H. Effect of cyanidin-3-glucoside and an anthocyanin mixture from bilberry on adenoma development in the Apc ${ }^{\text {Min }}$ mouse model of intestinal carcinogenesis-Relationship with tissue anthocyanin levels. Int. J. Cancer 2006, 119, 2213-2220. [CrossRef] [PubMed]

136. Hinoi, T.; Akyol, A.; Theisen, B.K.; Ferguson, D.O.; Greenson, J.K.; Williams, B.O.; Cho, K.R.; Fearon, E.R. Mouse model of colonic adenoma-carcinoma progression based on somatic Apc inactivation. Cancer Res. 2007, 67, 9721-9730. [CrossRef] [PubMed]

137. Biedermann, L.; Mwinyi, J.; Scharl, M.; Frei, P.; Zeitz, J.; Kullak-Ublick, G.A.; Vavricka, S.R.; Fried, M.; Weber, A.; Humpf, H.U.; et al. Bilberry ingestion improves disease activity in mild to moderate ulcerative colitis-An open pilot study. J. Crohns Colitis 2013, 7, 271-279. [CrossRef] [PubMed]

138. Roth, S.; Spalinger, M.R.; Gottier, C.; Biedermann, L.; Zeitz, J.; Lang, S.; Weber, A.; Rogler, G.; Scharl, M. Bilberry-Derived Anthocyanins Modulate Cytokine Expression in the Intestine of Patients with Ulcerative Colitis. PLoS ONE 2016, 11, e0154817. [CrossRef]

139. Thomasset, S.; Berry, D.P.; Cai, H.; West, K.; Marczylo, T.H.; Marsden, D.; Brown, K.; Dennison, A.; Garcea, G.; Miller, A.; et al. Pilot study of oral anthocyanins for colorectal cancer chemoprevention. Cancer Prev. Res. (Phila.) 2009, 2, 625-633. [CrossRef] [PubMed]

140. Wang, L.S.; Arnold, M.; Huang, Y.W.; Sardo, C.; Seguin, C.; Martin, E.; Huang, T.H.; Riedl, K.; Schwartz, S.; Frankel, W.; et al. Modulation of genetic and epigenetic biomarkers of colorectal cancer in humans by black raspberries: A phase I pilot study. Clin. Cancer Res. 2011, 17, 598-610. [CrossRef] [PubMed]

141. Hoenscell-cycle Arrestch, H.; Groh, B.; Edler, L.; Kirch, W. Prospective cohort comparison of flavonoid treatment in patients with resected colorectal cancer to prevent recurrence. World J. Gastroenterol. 2008, 14, 2187-2193.

142. Bobe, G.; Sansbury, L.B.; Albert, P.S.; Cross, A.J.; Kahle, L.; Ashby, J.; Slattery, M.L.; Caan, B.; Paskett, E.; Iber, F.; et al. Dietary flavonoids and colorectal adenoma recurrence in the Polyp Prevention Trial. Cancer Epidemiol. Biomark. Prev. 2008, 17, 1344-1353. [CrossRef] [PubMed]

143. Wang, W.; Heideman, L.; Chung, C.S.; Pelling, J.C.; Koehler, K.J.; Birt, D.F. Cell-cycle arrest at G2/M and growth inhibition by apigenin in human colon carcinoma cell lines. Mol. Carcinog. 2000, 28, 102-110. [CrossRef]

144. Wang, W.; VanAlstyne, P.C.; Irons, K.A.; Chen, S.; Stewart, J.W.; Birt, D.F. Individual and interactive effects of apigenin analogs on G2/M cell-cycle arrest in human colon carcinoma cell lines. Nutr. Cancer 2004, 48, 106-114. [CrossRef] [PubMed]

145. Chung, C.S.; Jiang, Y.; Cheng, D.; Birt, D.F. Impact of adenomatous polyposis coli (APC) tumor supressor gene in human colon cancer cell lines on cell cycle arrest by apigenin. Mol. Carcinog. 2007, 46, 773-782. [CrossRef]

146. Lee, Y.; Sung, B.; Kang, Y.J.; Kim, D.H.; Jang, J.Y.; Hwang, S.Y.; Kim, M.; Lim, H.S.; Yoon, J.H.; Chung, H.Y.; et al. Apigenin-induced apoptosis is enhanced by inhibition of autophagy formation in HCT116 human colon cancer cells. Int. J. Oncol. 2014, 44, 1599-1606. [CrossRef] [PubMed]

147. Banerjee, K.; Mandal, M. Oxidative stress triggered by naturally occurring flavone apigenin results in senescence and chemotherapeutic effect in human colorectal cancer cells. Redox Biol. 2015, 5, 153-162. [CrossRef] [PubMed]

148. Zhong, Y.; Krisanapun, C.; Lee, S.H.; Nualsanit, T.; Sams, C.; Peungvicha, P.; Baek, S.J. Molecular targets of apigenin in colorectal cancer cells: Involvement of p21, NAG-1 and p53. Eur. J. Cancer 2010, 46, 3365-3374. [CrossRef] [PubMed]

149. Chidambara Murthy, K.N.; Kim, J.; Vikram, A.; Patil, B.S. Differential inhibition of human colon cancer cells by structurally similar flavonoids of citrus. Food Chem. 2012, 132, 27-34. [CrossRef]

150. Lin, C.M.; Chen, H.H.; Lin, C.A.; Wu, H.C.; Sheu, J.J.; Chen, H.J. Apigenin-induced lysosomal degradation of beta-catenin in Wnt/beta-catenin signaling. Sci. Rep. 2017, 7, 372. [CrossRef] 
151. Xu, M.; Wang, S.; Song, Y.U.; Yao, J.; Huang, K.; Zhu, X. Apigenin suppresses colorectal cancer cell proliferation, migration and invasion via inhibition of the Wnt/beta-catenin signaling pathway. Oncol. Lett. 2016, 11, 3075-3080. [CrossRef]

152. Shan, S.; Shi, J.; Yang, P.; Jia, B.; Wu, H.; Zhang, X.; Li, Z. Apigenin Restrains Colon Cancer Cell Proliferation via Targeted Blocking of Pyruvate Kinase M2-Dependent Glycolysis. J. Agric. Food Chem. 2017, 65, 8136-8144. [CrossRef] [PubMed]

153. Van Dross, R.; Xue, Y.; Knudson, A.; Pelling, J.C. The chemopreventive bioflavonoid apigenin modulates signal transduction pathways in keratinocyte and colon carcinoma cell lines. J. Nutr. 2003, 133, 3800S-3804S. [CrossRef] [PubMed]

154. Au, A.; Li, B.; Wang, W.; Roy, H.; Koehler, K.; Birt, D. Effect of dietary apigenin on colonic ornithine decarboxylase activity, aberrant crypt foci formation, and tumorigenesis in different experimental models. Nutr. Cancer 2006, 54, 243-251. [CrossRef]

155. Luongo, C.; Moser, A.R.; Gledhill, S.; Dove, W.F. Loss of Apc+ in intestinal adenomas from Min mice. Cancer Res. 1994, 54, 5947-5952. [PubMed]

156. Leonardi, T.; Vanamala, J.; Taddeo, S.S.; Davidson, L.A.; Murphy, M.E.; Patil, B.S.; Wang, N.; Carroll, R.J.; Chapkin, R.S.; Lupton, J.R.; et al. Apigenin and naringenin suppress colon carcinogenesis through the aberrant crypt stage in azoxymethane-treated rats. Exp. Biol. Med. 2010, 235, 710-717. [CrossRef] [PubMed]

157. Zhang, W.; Qiao, H.; Lv, Y.; Wang, J.; Chen, X.; Hou, Y.; Tan, R.; Li, E. Apigenin inhibits enterovirus-71 infection by disrupting viral RNA association with trans-acting factors. PLoS ONE 2014, 9, e110429. [CrossRef] [PubMed]

158. Marquez-Flores, Y.K.; Villegas, I.; Cardeno, A.; Rosillo, M.A.; Alarcon-de-la-Lastra, C. Apigenin supplementation protects the development of dextran sulfate sodium-induced murine experimental colitis by inhibiting canonical and non-canonical inflammasome signaling pathways. J. Nutr. Biochem. 2016, 30, 143-152. [CrossRef] [PubMed]

159. Ai, X.Y.; Qin, Y.; Liu, H.J.; Cui, Z.H.; Li, M.; Yang, J.H.; Zhong, W.L.; Liu, Y.R.; Chen, S.; Sun, T.; et al. Apigenin inhibits colonic inflammation and tumorigenesis by suppressing STAT3-NF-kappaB signaling. Oncotarget 2017, 8, 100216-100226. [CrossRef]

160. Radulovic, K.; Normand, S.; Rehman, A.; Delanoye-Crespin, A.; Chatagnon, J.; Delacre, M.; Waldschmitt, N.; Poulin, L.F.; Iovanna, J.; Ryffel, B.; et al. A dietary flavone confers communicable protection against colitis through NLRP6 signaling independently of inflammasome activation. Mucosal Immunol. 2018, 11, 811-819. [CrossRef]

161. Levy, M.; Thaiss, C.A.; Zeevi, D.; Dohnalova, L.; Zilberman-Schapira, G.; Mahdi, J.A.; David, E.; Savidor, A.; Korem, T.; Herzig, Y.; et al. Microbiota-Modulated Metabolites Shape the Intestinal Microenvironment by Regulating NLRP6 Inflammasome Signaling. Cell 2015, 163, 1428-1443. [CrossRef]

162. Elinav, E.; Strowig, T.; Kau, A.L.; Henao-Mejia, J.; Thaiss, C.A.; Booth, C.J.; Peaper, D.R.; Bertin, J.; Eisenbarth, S.C.; Gordon, J.I.; et al. NLRP6 inflammasome regulates colonic microbial ecology and risk for colitis. Cell 2011, 145, 745-757. [CrossRef] [PubMed]

163. Normand, S.; Delanoye-Crespin, A.; Bressenot, A.; Huot, L.; Grandjean, T.; Peyrin-Biroulet, L.; Lemoine, Y.; Hot, D.; Chamaillard, M. Nod-like receptor pyrin domain-containing protein 6 (NLRP6) controls epithelial self-renewal and colorectal carcinogenesis upon injury. Proc. Natl. Acad. Sci. USA 2011, 108, 9601-9606. [CrossRef] [PubMed]

164. Chen, G.Y.; Liu, M.; Wang, F.; Bertin, J.; Nunez, G. A functional role for Nlrp6 in intestinal inflammation and tumorigenesis. J. Immunol. 2011, 186, 7187-7194. [CrossRef] [PubMed]

165. Wang, M.; Firrman, J.; Zhang, L.; Arango-Argoty, G.; Tomasula, P.; Liu, L.; Xiao, W.; Yam, K. Apigenin Impacts the Growth of the Gut Microbiota and Alters the Gene Expression of Enterococcus. Molecules 2017, 22, 1292. [CrossRef] [PubMed]

166. Kim, W.K.; Bang, M.H.; Kim, E.S.; Kang, N.E.; Jung, K.C.; Cho, H.J.; Park, J.H. Quercetin decreases the expression of ErbB2 and ErbB3 proteins in HT-29 human colon cancer cells. J. Nutr. Biochem. 2005, 16, 155-162. [CrossRef] [PubMed]

167. Kim, H.J.; Kim, S.K.; Kim, B.S.; Lee, S.H.; Park, Y.S.; Park, B.K.; Kim, S.J.; Kim, J.; Choi, C.; Kim, J.S.; et al. Apoptotic effect of quercetin on HT-29 colon cancer cells via the AMPK signaling pathway. J. Agric. Food Chem. 2010, 58, 8643-8650. [CrossRef] [PubMed] 
168. Van Erk, M.J.; Roepman, P.; van der Lende, T.R.; Stierum, R.H.; Aarts, J.M.; van Bladeren, P.J.; van Ommen, B. Integrated assessment by multiple gene expression analysis of quercetin bioactivity on anticancer-related mechanisms in colon cancer cells in vitro. Eur. J. Nutr. 2005, 44, 143-156. [CrossRef] [PubMed]

169. Shan, B.E.; Wang, M.X.; Li, R.Q. Quercetin inhibit human SW480 colon cancer growth in association with inhibition of cyclin D1 and survivin expression through Wnt/beta-catenin signaling pathway. Cancer Investig. 2009, 27, 604-612. [CrossRef]

170. Hosokawa, N.; Hosokawa, Y.; Sakai, T.; Yoshida, M.; Marui, N.; Nishino, H.; Kawai, K.; Aoike, A. Inhibitory effect of quercetin on the synthesis of a possibly cell-cycle-related 17-kDa protein, in human colon cancer cells. Int. J. Cancer 1990, 45, 1119-1124. [CrossRef]

171. Chan, A.T.; Ogino, S.; Fuchs, C.S. Aspirin and the risk of colorectal cancer in relation to the expression of COX-2. N. Engl. J. Med. 2007, 356, 2131-2142. [CrossRef]

172. Park, C.H.; Chang, J.Y.; Hahm, E.R.; Park, S.; Kim, H.K.; Yang, C.H. Quercetin, a potent inhibitor against beta-catenin/Tcf signaling in SW480 colon cancer cells. Biochem. Biophys. Res. Commun. 2005, 328, 227-234. [CrossRef] [PubMed]

173. Darband, S.G.; Kaviani, M.; Yousefi, B.; Sadighparvar, S.; Pakdel, F.G.; Attari, J.A.; Mohebbi, I.; Naderi, S.; Majidinia, M. Quercetin: A functional dietary flavonoid with potential chemo-preventive properties in colorectal cancer. J. Cell. Physiol. 2018, 233, 6544-6560. [CrossRef] [PubMed]

174. Refolo, M.G.; D’Alessandro, R.; Malerba, N.; Laezza, C.; Bifulco, M.; Messa, C.; Caruso, M.G.; Notarnicola, M.; Tutino, V. Anti Proliferative and Pro Apoptotic Effects of Flavonoid Quercetin Are Mediated by CB1 Receptor in Human Colon Cancer Cell Lines. J. Cell. Physiol. 2015, 230, 2973-2980. [CrossRef] [PubMed]

175. Deschner, E.E.; Ruperto, J.; Wong, G.; Newmark, H.L. Quercetin and rutin as inhibitors of azoxymethanol-induced colonic neoplasia. Carcinogenesis 1991, 12, 1193-1196. [CrossRef] [PubMed]

176. Warren, C.A.; Paulhill, K.J.; Davidson, L.A.; Lupton, J.R.; Taddeo, S.S.; Hong, M.Y.; Carroll, R.J.; Chapkin, R.S.; Turner, N.D. Quercetin may suppress rat aberrant crypt foci formation by suppressing inflammatory mediators that influence proliferation and apoptosis. J. Nutr. 2009, 139, 101-105. [CrossRef] [PubMed]

177. Volate, S.R.; Davenport, D.M.; Muga, S.J.; Wargovich, M.J. Modulation of aberrant crypt foci and apoptosis by dietary herbal supplements (quercetin, curcumin, silymarin, ginseng and rutin). Carcinogenesis 2005, 26, 1450-1456. [CrossRef] [PubMed]

178. Yang, K.; Lamprecht, S.A.; Liu, Y.; Shinozaki, H.; Fan, K.; Leung, D.; Newmark, H.; Steele, V.E.; Kelloff, G.J.; Lipkin, M. Chemoprevention studies of the flavonoids quercetin and rutin in normal and azoxymethane-treated mouse colon. Carcinogenesis 2000, 21, 1655-1660. [CrossRef] [PubMed]

179. Huang, J.; Chen, L.; Xue, B.; Liu, Q.; Ou, S.; Wang, Y.; Peng, X. Different Flavonoids Can Shape Unique Gut Microbiota Profile In Vitro. J. Food Sci. 2016, 81, H2273-H2279. [CrossRef] [PubMed]

180. Ju, S.; Ge, Y.; Li, P.; Tian, X.; Wang, H.; Zheng, X.; Ju, S. Dietary quercetin ameliorates experimental colitis in mouse by remodeling the function of colonic macrophages via a heme oxygenase-1-dependent pathway. Cell Cycle 2018, 17, 53-63. [CrossRef]

181. Mukhopadhya, I.; Hansen, R.; El-Omar, E.M.; Hold, G.L. IBD-what role do Proteobacteria play? Nat. Rev. Gastroenterol. Hepatol. 2012, 9, 219-230. [CrossRef]

182. Hughes, E.R.; Winter, M.G.; Duerkop, B.A.; Spiga, L.; Furtado de Carvalho, T.; Zhu, W.; Gillis, C.C.; Buttner, L.; Smoot, M.P.; Behrendt, C.L.; et al. Microbial Respiration and Formate Oxidation as Metabolic Signatures of Inflammation-Associated Dysbiosis. Cell Host Microbe 2017, 21, 208-219. [CrossRef] [PubMed]

183. Ivanov, I.I.; Atarashi, K.; Manel, N.; Brodie, E.L.; Shima, T.; Karaoz, U.; Wei, D.; Goldfarb, K.C.; Santee, C.A.; Lynch, S.V.; et al. Induction of intestinal Th17 cells by segmented filamentous bacteria. Cell 2009, 139, 485-498. [CrossRef] [PubMed]

184. Rossi, M.; Negri, E.; Talamini, R.; Bosetti, C.; Parpinel, M.; Gnagnarella, P.; Franceschi, S.; Dal Maso, L.; Montella, M.; Giacosa, A.; et al. Flavonoids and colorectal cancer in Italy. Cancer Epidemiol. Biomark. Prev. 2006, 15, 1555-1558. [CrossRef] [PubMed]

185. Lin, J.; Zhang, S.M.; Wu, K.; Willett, W.C.; Fuchs, C.S.; Giovannucci, E. Flavonoid intake and colorectal cancer risk in men and women. Am. J. Epidemiol. 2006, 164, 644-651. [CrossRef] [PubMed]

186. Djuric, Z.; Severson, R.K.; Kato, I. Association of dietary quercetin with reduced risk of proximal colon cancer. Nutr. Cancer 2012, 64, 351-360. [CrossRef] 
187. Egert, S.; Wolffram, S.; Schulze, B.; Langguth, P.; Hubbermann, E.M.; Schwarz, K.; Adolphi, B.; Bosy-Westphal, A.; Rimbach, G.; Muller, M.J. Enriched cereal bars are more effective in increasing plasma quercetin compared with quercetin from powder-filled hard capsules. Br. J. Nutr. 2012, 107, 539-546. [CrossRef]

188. Rupasinghe, H.P.; Erkan, N.; Yasmin, A. Antioxidant protection of eicosapentaenoic acid and fish oil oxidation by polyphenolic-enriched apple skin extract. J. Agric. Food Chem. 2010, 58, 1233-1239. [CrossRef]

189. Fujiki, H.; Sueoka, E.; Watanabe, T.; Suganuma, M. Primary cancer prevention by green tea, and tertiary cancer prevention by the combination of green tea catechins and anticancer compounds. J. Cancer Prev. 2015, 20, 1-4. [CrossRef]

190. Shin, C.M.; Lee, D.H.; Seo, A.Y.; Lee, H.J.; Kim, S.B.; Son, W.C.; Kim, Y.K.; Lee, S.J.; Park, S.H.; Kim, N.; et al. Green tea extracts for the prevention of metachronous colorectal polyps among patients who underwent endoscopic removal of colorectal adenomas: A randomized clinical trial. Clin. Nutr. 2018, 37, 452-458. [CrossRef]

191. Sun, C.L.; Yuan, J.M.; Koh, W.P.; Yu, M.C. Green tea, black tea and colorectal cancer risk: A meta-analysis of epidemiologic studies. Carcinogenesis 2006, 27, 1301-1309. [CrossRef]

192. Shimizu, M.; Fukutomi, Y.; Ninomiya, M.; Nagura, K.; Kato, T.; Araki, H.; Suganuma, M.; Fujiki, H.; Moriwaki, H. Green tea extracts for the prevention of metachronous colorectal adenomas: A pilot study. Cancer Epidemiol. Biomark. Prev. 2008, 17, 3020-3025. [CrossRef] [PubMed]

193. Toden, S.; Tran, H.M.; Tovar-Camargo, O.A.; Okugawa, Y.; Goel, A. Epigallocatechin-3-gallate targets cancer stem-like cells and enhances 5-fluorouracil chemosensitivity in colorectal cancer. Oncotarget 2016, 7, 16158-16171. [CrossRef] [PubMed]

194. Chen, Y.; Wang, X.Q.; Zhang, Q.; Zhu, J.Y.; Li, Y.; Xie, C.F.; Li, X.T.; Wu, J.S.; Geng, S.S.; Zhong, C.Y.; et al. (-)-Epigallocatechin-3-Gallate Inhibits Colorectal Cancer Stem Cells by Suppressing Wnt/beta-Catenin Pathway. Nutrients 2017, 9, 572. [CrossRef] [PubMed]

195. Oh, S.; Gwak, J.; Park, S.; Yang, C.S. Green tea polyphenol EGCG suppresses Wnt/beta-catenin signaling by promoting GSK-3beta- and PP2A-independent beta-catenin phosphorylation/degradation. Biofactors 2014, 40, 586-595. [CrossRef] [PubMed]

196. Peng, G.; Dixon, D.A.; Muga, S.J.; Smith, T.J.; Wargovich, M.J. Green tea polyphenol (-)-epigallocatechin-3-gallate inhibits cyclooxygenase-2 expression in colon carcinogenesis. Mol. Carcinog. 2006, 45, 309-319. [CrossRef] [PubMed]

197. Chen, C.; Shen, G.; Hebbar, V.; Hu, R.; Owuor, E.D.; Kong, A.N. Epigallocatechin-3-gallate-induced stress signals in HT-29 human colon adenocarcinoma cells. Carcinogenesis 2003, 24, 1369-1378. [CrossRef] [PubMed]

198. Ni, J.; Guo, X.; Wang, H.; Zhou, T.; Wang, X. Differences in the Effects of EGCG on Chromosomal Stability and Cell Growth between Normal and Colon Cancer Cells. Molecules 2018, 23, 788. [CrossRef] [PubMed]

199. Valcic, S.; Muders, A.; Jacobsen, N.E.; Liebler, D.C.; Timmermann, B.N. Antioxidant chemistry of green tea catechins. Identification of products of the reaction of (-)-epigallocatechin gallate with peroxyl radicals. Chem. Res. Toxicol. 1999, 12, 382-386. [CrossRef]

200. Li, G.X.; Chen, Y.K.; Hou, Z.; Xiao, H.; Jin, H.; Lu, G.; Lee, M.J.; Liu, B.; Guan, F.; Yang, Z.; et al. Pro-oxidative activities and dose-response relationship of (-)-epigallocatechin-3-gallate in the inhibition of lung cancer cell growth: A comparative study in vivo and in vitro. Carcinogenesis 2010, 31, 902-910. [CrossRef]

201. Kim, H.S.; Quon, M.J.; Kim, J.A. New insights into the mechanisms of polyphenols beyond antioxidant properties; lessons from the green tea polyphenol, epigallocatechin 3-gallate. Redox Biol. 2014, 2, 187-195. [CrossRef]

202. Fang, M.Z.; Wang, Y.; Ai, N.; Hou, Z.; Sun, Y.; Lu, H.; Welsh, W.; Yang, C.S. Tea polyphenol (-)-epigallocatechin-3-gallate inhibits DNA methyltransferase and reactivates methylation-silenced genes in cancer cell lines. Cancer Res. 2003, 63, 7563-7570. [PubMed]

203. Moseley, V.R.; Morris, J.; Knackstedt, R.W.; Wargovich, M.J. Green tea polyphenol epigallocatechin 3-gallate, contributes to the degradation of DNMT3A and HDAC3 in HCT 116 human colon cancer cells. Anticancer Res. 2013, 33, 5325-5333. [PubMed]

204. Morris, J.; Moseley, V.R.; Cabang, A.B.; Coleman, K.; Wei, W.; Garrett-Mayer, E.; Wargovich, M.J. Reduction in promotor methylation utilizing EGCG (epigallocatechin-3-gallate) restores RXRalpha expression in human colon cancer cells. Oncotarget 2016, 7, 35313-35326. [CrossRef] 
205. Ogawa, K.; Hara, T.; Shimizu, M.; Ninomiya, S.; Nagano, J.; Sakai, H.; Hoshi, M.; Ito, H.; Tsurumi, H.; Saito, K.; et al. Suppression of azoxymethane-induced colonic preneoplastic lesions in rats by 1-methyltryptophan, an inhibitor of indoleamine 2,3-dioxygenase. Cancer Sci. 2012, 103, 951-958. [CrossRef] [PubMed]

206. Yamane, T.; Nakatani, H.; Kikuoka, N.; Matsumoto, H.; Iwata, Y.; Kitao, Y.; Oya, K.; Takahashi, T. Inhibitory effects and toxicity of green tea polyphenols for gastrointestinal carcinogenesis. Cancer 1996, 77, 1662-1667. [CrossRef]

207. Yuan, X.; Long, Y.; Ji, Z.; Gao, J.; Fu, T.; Yan, M.; Zhang, L.; Su, H.; Zhang, W.; Wen, X.; et al. Green Tea Liquid Consumption Alters the Human Intestinal and Oral Microbiome. Mol. Nutr. Food Res. 2018, 62, e1800178. [CrossRef] [PubMed]

208. Chen, W.; Liu, F.; Ling, Z.; Tong, X.; Xiang, C. Human intestinal lumen and mucosa-associated microbiota in patients with colorectal cancer. PLoS ONE 2012, 7, e39743. [CrossRef] [PubMed]

209. Zamora-Ros, R.; Barupal, D.K.; Rothwell, J.A.; Jenab, M.; Fedirko, V.; Romieu, I.; Aleksandrova, K.; Overvad, K.; Kyro, C.; Tjonneland, A.; et al. Dietary flavonoid intake and colorectal cancer risk in the European prospective investigation into cancer and nutrition (EPIC) cohort. Int. J. Cancer 2017, 140, 1836-1844. [CrossRef] [PubMed]

210. He, X.; Sun, L.M. Dietary intake of flavonoid subclasses and risk of colorectal cancer: Evidence from population studies. Oncotarget 2016, 7, 26617-26627. [CrossRef] [PubMed]

211. Turnbaugh, P.J.; Hamady, M.; Yatsunenko, T.; Cantarel, B.L.; Duncan, A.; Ley, R.E.; Sogin, M.L.; Jones, W.J.; Roe, B.A.; Affourtit, J.P.; et al. A core gut microbiome in obese and lean twins. Nature 2009, 457, 480-484. [CrossRef] [PubMed]

(C) 2018 by the authors. Licensee MDPI, Basel, Switzerland. This article is an open access article distributed under the terms and conditions of the Creative Commons Attribution (CC BY) license (http://creativecommons.org/licenses/by/4.0/). 